\title{
Dynamical forcings in heavy precipitation events over Italy: lessons from the HyMeX SOP1 campaign
}

\author{
Mario Marcello Miglietta ${ }^{1}$ and Silvio Davolio ${ }^{2}$ \\ ${ }^{1}$ National Research Council of Italy, Institute of Atmospheric Sciences and Climate (CNR-ISAC), Padua, 35127, Italy \\ ${ }^{2}$ National Research Council of Italy, Institute of Atmospheric Sciences and Climate (CNR-ISAC), Bologna, 40129, Italy
}

Correspondence: Mario Marcello Miglietta (m.miglietta@isac.cnr.it)

Received: 12 May 2021 - Discussion started: 25 May 2021

Revised: 13 September 2021 - Accepted: 12 January 2022 - Published: 9 February 2022

\begin{abstract}
The first Special Observation Period (SOP1) of HyMeX (Hydrological cycle in the Mediterranean eXperiment) was held in fall 2012 and focused on heavy precipitation events (HPEs) and floods in the northwestern Mediterranean. Nine intensive observation periods (IOPs) involved three Italian target areas (northeastern Italy, NEI; Liguria and Tuscany, LT; central Italy, CI), enabling an unprecedented analysis of precipitation systems in these regions. In the present work, we highlight the major findings emerging from the HyMeX campaign and in the subsequent research activity over the three target areas by means of conceptual models and through the identification of the relevant recursive mesoscale features.

For NEI, two categories of events (Upstream and Alpine HPEs) were identified, which differ mainly in the temporal evolution of the stability of the upstream environment and of the intensity of the impinging flow. The numerical simulation of convection in the Po Valley was found to be very sensitive to small changes in the environmental conditions, especially when they are close to the threshold between "flow-over" and "flow-around" regimes.

For LT, HyMeX SOP1 focused on orographically enhanced precipitation over the Apennines and quasi-stationary mesoscale convective systems over the sea or close to the coast. For the latter category of events, associated with the majority of the recent HPEs, local-scale or large-scale convergence lines appear fundamental to trigger and sustain convection. These lines are affected not only by the orography of the region, but also by the perturbations induced by Sardinia and Corsica on the environmental flow, and, at later times, by cold pools formed via evaporation of precipitation.
\end{abstract}

For CI, a high low-level moisture content and marked lowlevel convergence over the sea were critical to support deep convection in the IOPs affecting the Tyrrhenian coast. For the HPEs affecting the Adriatic regions, a cut-off low over the Tyrrhenian Sea induces intense bora over the Adriatic basin. Low-level convergence triggers convection over the sea, while orographic uplift produces stratiform precipitation. The Adriatic Sea plays a critical role mainly through air-sea exchanges, which modify the characteristics of the flow and in turn the effect of the orographic forcing.

\section{Introduction}

The peculiar characteristics of the Mediterranean region, a nearly enclosed basin surrounded by complex terrain close to the coast, makes the area particularly prone to natural hazards related to the water cycle. Intense events, such as heavy rainfall and floods, still pose a significant threat to people (Llasat et al., 2013) despite the noteworthy improvements in forecasting, emergency management, and defensive measures. Hence, the interest in improving the understanding and forecasting of severe weather events is clear for both scientific research and operational activities.

The Hydrological cycle in the Mediterranean eXperiment (HyMeX, http://www.hymex.org, last access: 4 February 2022; Drobinski et al., 2014) was an international program devoted to advancing scientific knowledge of the water cycle in the Mediterranean basin. This goal was pursued through the monitoring, analysis, and modeling of the regional hydrometeorological cycle in a seamless approach. Phenomena were investigated at different temporal and spa- 
tial scales, ranging from the inter-annual/decadal variability of the atmosphere-land-ocean coupled system to single case studies of severe weather. The experimental activity, a key component of HyMeX, was based on atmospheric, oceanic, and hydrological monitoring covering a period of 10 years from 2010 to 2020 . Within this time frame, Special Observation Periods (SOPs), shorter periods of intensive monitoring, were planned. In particular, the first Special Observation Period (SOP1), between 5 September and 6 November 2012, focused on heavy precipitation events (HPEs) and floods in the western Mediterranean (WMED). During SOP1, 20 intensive observation periods (IOPs) were undertaken (Ducrocq et al., 2014), 9 of which involved the Italian regions (see Table 5 in Ferretti et al., 2014). The second field campaign, named SOP2, took place in winter 2013 (February-March) and was dedicated to the study of intense air-sea exchanges and dense water formation. HyMeX thoroughly investigated the processes responsible for HPEs, including the origin of moist air masses in pre-convective conditions (Duffourg and Ducrocq, 2011, 2013; Duffourg et al., 2018; Flaounas et al., 2019; Lee et al., 2019) and the link between these air masses and intense rainfall. During SOP1, dedicated observing platforms were managed with the objective of documenting the connection between moist flows and HPEs over the coastal areas of the WMED (Ducrocq et al., 2014; Bock et al., 2016; Lee et al., 2017; Khodayar et al., 2018).

The need for progress in the monitoring and prediction of these events, with the purpose of preventing or reducing societal losses, represented the strong motivation that induced a broad and active participation of the Italian community in SOP1 (Ferretti et al., 2014; Davolio et al., 2015a). The activities carried out during the field campaign and planned for the upcoming years represented a unique opportunity for the study of intense orographic precipitation, exploiting the synergy between observations and available model simulations. The Italian peninsula, extending from the southern Alps in the north to the central Mediterranean Sea in the south, is particularly exposed to natural hazards associated with the water cycle and to the consequent hydrogeological effects, often amplified by its complex morphology; thus, the scientific aims of HyMeX were particularly relevant for the Italian territory. The steep slopes of the Alps and the Apennines in the proximity of the Mediterranean, and the Mediterranean Sea itself, which acts as a source of moisture and heat, are key factors in determining the convergence and the uplift of moist and unstable air masses, which are responsible for triggering convection over Italy and the surrounding seas. Moreover, HPEs persisting for several hours within the small and densely urbanized watersheds with steep slopes, which characterize the Italian area, can generate devastating floods in a relatively short time (Silvestro et al., 2012; Vulpiani et al., 2012; Buzzi et al., 2014; Gascon et al., 2016; Fiori et al., 2017). The national socioeconomic impact of these kinds of events is relevant, as indicated by the high number of casu- alties and damages reported in recent years (e.g., Guzzetti et al., 2005; Salvati et al., 2010).

Among the target areas in the WMED basin monitored during the field campaign, three were selected in Italy (Fig. 1): an Alpine/pre-Alpine site in northeastern Italy (NEI), characterized by the maximum amount of mean annual precipitation (Isotta et al., 2014), two target areas in regions frequently affected by HPEs, such as Liguria and Tuscany (LT; e.g., Rebora et al., 2013), and central Italy (CI; Ferretti et al., 2012). The extraordinary deployment of advanced instrumentation, including aircrafts, and the availability of several weather, hydrological, and ocean models operated in real time, allowed an unprecedented monitoring and analysis of HPEs in Italy. The activity stimulated the collaboration in the Italian meteorological community and reduced its traditional fragmentation. Davolio et al. (2015a) described the remarkable organizational efforts and daily activities at the HyMeX national Virtual Operational Centre (VOC), hosted by the Center of Excellence in Telesensing of Environment and Model Prediction of Severe events (CETEMPS) in L'Aquila during SOP1: scientists and forecasters from 14 research and operational Italian institutions moved to the VOC in weekly shifts, promoting a fruitful collaboration. The VOC supported the main HyMeX Operational Centre (HOC) in Montpellier (France), providing, analyzing, and discussing numerical weather prediction (NWP) model outputs and nearly real-time observations during the international briefings, thus contributing to the success of the field campaign. On the other hand, Ferretti et al. (2014) provided a scientific overview of some events that affected the Italian area during SOP1, investigating in detail the response of the different operational modeling chains specifically for three case studies (IOP2, IOP13, and IOP19), characterized initially by convection over the sea and orographic precipitation at later times.

During SOP1, negative or slightly positive values of the North Atlantic Oscillation (NAO) index prevailed, favoring cyclonic circulation and making the environmental conditions prone to precipitation systems crossing southern Europe. Several troughs entered the WMED and reached the Italian regions after having affected other target areas over Spain or France, often producing westerly-southwesterly flow over Italy (IOP2, IOP6, IOP7b, IOP12, IOP19); occasionally, mesoscale cyclones developed (IOP4, IOP16a), and, in a few events, lee cyclogenesis occurred over the Gulf of Genoa or a deep trough formed over the Tyrrhenian Sea (IOP13, IOP16c, IOP18). In general, the monthly precipitation amounts were close to the climatological values in September but well above in October (Khodayar et al., 2016); the most affected sites were the Cévennes-Vivarais (CV), the French southern Alps, as well as the LT target area in Italy.

The purpose of the present paper is to summarize what we know about the mechanisms responsible for HPEs in the three Italian target areas, highlighting the main findings emerging from the HyMeX campaign and the subsequent sci- 


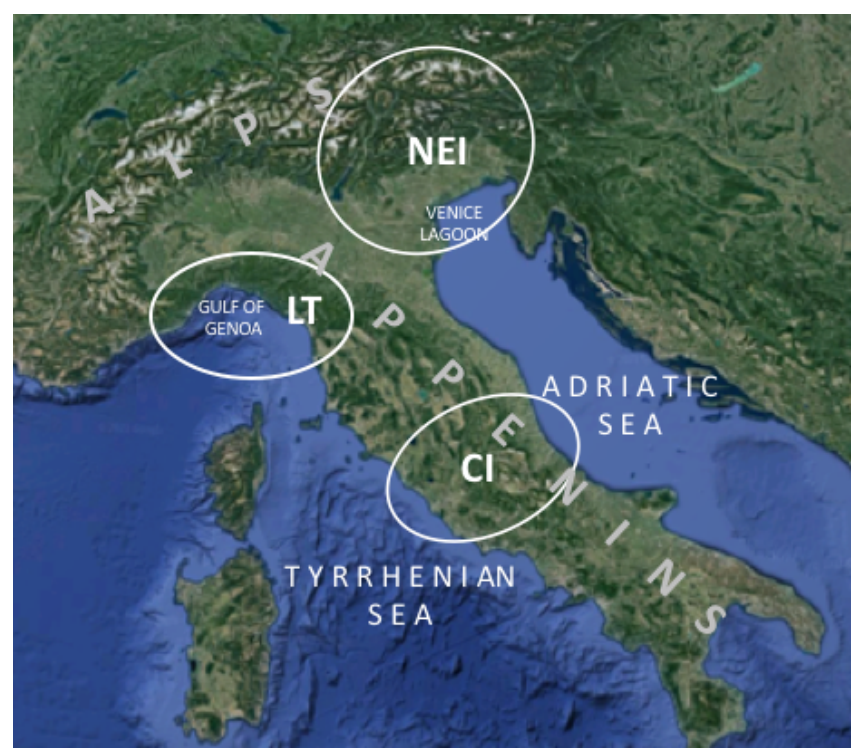

Figure 1. Italian target areas and geographic places mentioned in the text (figure background from Imagery (C) 2021 Landsat/Copernicus, data SIO, NOAA, U.S. Navy, NGA, GEBCO, and Imagery (C) 2021 TerraMetrics, and map data (C) 2021 GeoBasisDE/BKG, (C) Google 2009, and Inst. Geogr. Nacional).

entific activity, also using conceptual models to summarize the main factors responsible for these events. In these efforts, Sect. 2 provides a general overview of our knowledge on HPEs in the WMED region, while Sect. 3 is dedicated to the main results for the three Italian target areas (NEI, LT, CEI). Conclusions are drawn in Sect. 4.

\section{An overview of western Mediterranean HPEs}

The synoptic settings conducive to HPEs in the WMED are relatively well known from past international field campaigns, such as the Mesoscale Alpine Programme (MAP, Bougeault et al., 2001), the Medex project (Jansa et al., 2014), and subsequent studies (Rotunno and Houze, 2007; Nuissier et al., 2008; Winschall et al., 2012; Grazzini et al., 2019). In some areas, like the Alps, they are often characterized by higher-than-average predictability (e.g., Grazzini, 2007); thus, provided sufficient resolution, they are adequately simulated by numerical weather prediction models, at least at short leading times. HPEs on the northern coasts of the WMED often develop eastward of an upperlevel trough (Nuissier et al., 2011) deepening over the basin, which is responsible for steering warm and moist low-level unstable flow from the sea (characterized by high values of equivalent potential temperature and precipitable water) towards the mountainous coasts of the region. Lee cyclogenesis (Buzzi et al., 2003), frontal interaction with the Alps (Buzzi and Alberoni, 1992), low-level flow modifications due to the shape of the mountain barrier and to humidity/stability gra- dients (Rotunno and Ferretti, 2001), and moisture supply by air masses flowing over the western Mediterranean, sometimes organized as low-level jet streams ${ }^{1}$ (Stensrud, 1996; Buzzi and Foschini, 2000), represent mechanisms contributing to HPEs, which have received particular attention so far. Furthermore, Jansa et al. (2001) indicated that about $90 \%$ of the HPEs in the WMED involve the presence of a cyclonic center in their vicinity, usually in locations favorable to the creation and intensification of a low-level flow favoring convective initiation.

However, a lot of uncertainty is still associated with the description and accurate simulation of the mesoscale processes and mechanisms conducive to the initiation and intensification of precipitation systems, especially when convection dominates. Hence, the HyMeX field campaign was entirely devoted to investigating the small scales of convection down to microphysics and to providing new evidence and crucial insights into the genesis and evolution of quasistationary mesoscale convective systems (MCSs) in a complex topographic environment.

Idealized studies of moist flow interacting with orography (e.g., Miglietta and Buzzi, 2001, 2004; Miglietta and Rotunno, 2009, 2010; Davolio et al., 2009; Bresson et al., 2012; Kirshbaum et al., 2019) represent the cornerstone and the reference for the interpretation of new results. They have shown that the environmental conditions, including the characteristics of the upstream flow, may affect the mechanisms that trigger convection, such as orographic lifting, low-level wind convergence, and cold pool formation (Ducrocq et al., 2008, 2016).

When HPEs are observed near the mountains or at some distance upstream, deep convection is likely triggered by the direct orographic uplift or by the deflection or blocking action exerted by the orography, which renew convection triggering at the same location (Davolio et al., 2006). As long as the same environmental conditions persist, a back-building process may operate: new convective cells are repeatedly triggered at the same location, while older cells are transported downstream by the mid- to upper-level steering flow (Chen and Lin, 2005; Miglietta and Rotunno, 2014). This topic received a lot of benefits from the HyMeX research outcomes, as further detailed in the following. Figure 2 shows the typical configuration for MCS development in southern France, but similar conditions are associated with HPEs in the other regions of the northern side of the WMED, such as the LT target area or the northern Adriatic region.

Convective initiation may also occur over the sea and over the plains. In such a case, mechanisms of convection triggering and sustainment other than the direct orographic uplift may occur, such as the persistent low-level convergence induced by the alteration of the low-level flow by mountains and islands. In more detail, convergence can be associated

\footnotetext{
${ }^{1}$ A synoptically forced low-level jet is usually termed a "lowlevel jet stream".
} 


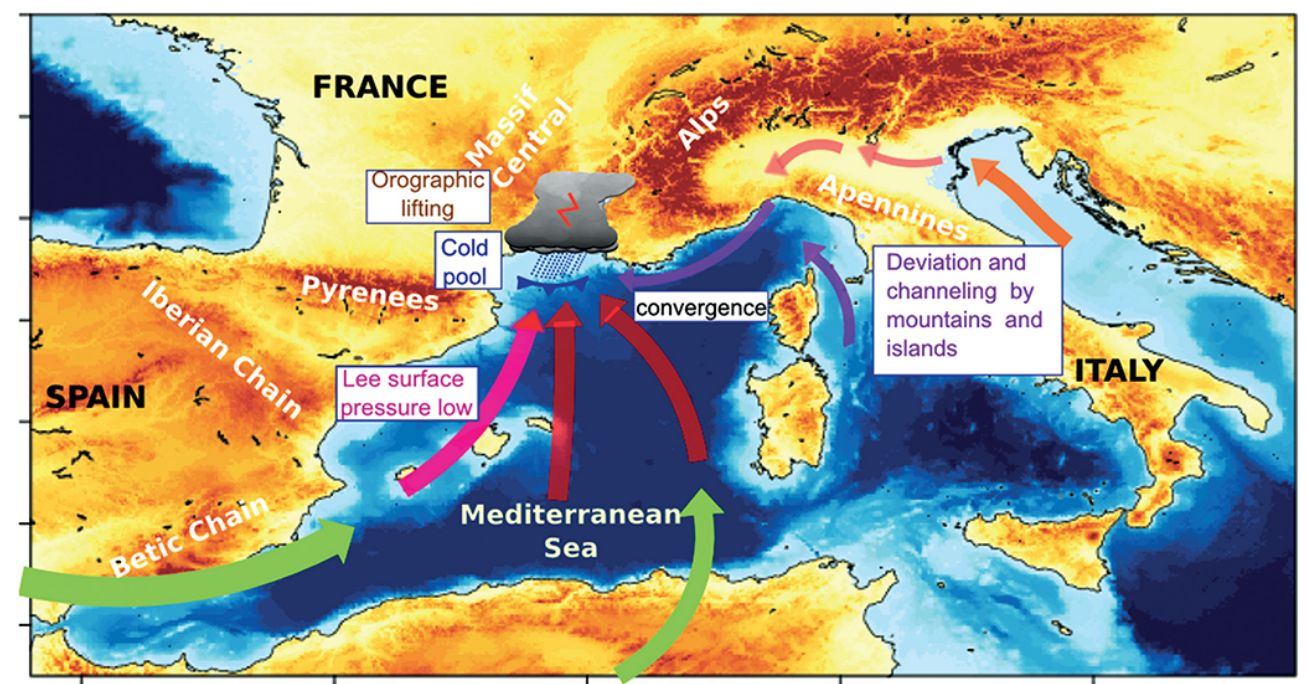

Figure 2. Schematic of the main low-level mechanisms responsible for a sample case of a HPE in the western Mediterranean region together with geographical locations (from Ducrocq et al., 2016).

with flow blocking and deflection or channeling by the complex orography surrounding the basin, which also constrains the moisture transport in the area (Bresson et al., 2012; Buzzi et al., 2014; Barthlott and Davolio, 2016; Scheffknecht et al., 2016), an even shallow cyclonic circulation (Duffourg et al., 2016; Khodayar et al., 2016), a frontal passage (Lee et al., 2016), and the interaction between sea breezes and drainage winds induced by mountainous islands, like Corsica or Sardinia (Barthlott and Kirshbaum, 2013). Often, it is the interplay of different factors that allows the development of MCSs (Lee et al., 2017). Occasionally, the transport of water vapor within thermally driven circulations, such as valley winds, slope winds, and sea breezes, may cause spatial inhomogeneities in the pre-convective conditions and in the development of isolated deep convection (Adler et al., 2016).

In any case, a low-level evaporative cold pool, whose intensity is modulated by the moisture vertical distribution (Lee et al., 2016, 2018), may form under the MCS, and it behaves as an obstacle (Duffourg et al., 2016; Bouin et al., 2017) that lifts the low-level flow at its leading edge or locally modifies the low-level circulation, even enhancing flow convergence and upward motion (Duffourg et al., 2016). Cold pools may remain stationary when counteracted by the environmental flow (Miglietta and Rotunno, 2012; Davolio et al., 2016), generating quasi-stationary MCSs. Moreover, once the convective system is formed, it may interact with the mountains and islands of the region, and the cold pool may be blocked or may even push the MCS upstream away from the mountain barrier (Duffourg et al., 2018). This cold-pool convection-triggering mechanism occurs more frequently when the ambient flow is relatively dry or weak (Bresson et al., 2012). In these conditions, accurate rainfall prediction requires a detailed description of the low-level vertical moisture distribution (Lee et al., 2018): the variabil- ity and stratification of atmospheric moisture in the lower troposphere determines when, where, and how intense convection will develop and whether a cold pool may form (Lee et al., 2016).

In many cases, multi-cell V-shaped MCSs have been observed (Davolio et al., 2009; Rebora et al., 2013; Lee et al., 2016), often forming just offshore. These systems are characterized by retrograde regeneration (a "back-building" process - e.g., Schumacher and Johnson, 2005), since convective cells are repeatedly generated upstream while older cells move downstream. Thus, they appear anchored over the sea, but intense convective cells and precipitation may also affect the inland (Duffourg et al., 2016; Buzzi et al., 2014; Fiori et al., 2017). The complex multi-scale interaction among the moist ambient inflow, extracting moisture and heat from the sea surface, deep convection, and topography makes difficult the precise prediction of the timing, location, and amount of precipitation associated with these systems.

Determinant for the development of precipitating convection in the WMED is the presence of moisture, which may originate from either remote or local sources (Ricard et al., 2012; Krichak et al., 2015; Khodayar et al., 2016). Depending on the synoptic conditions, the Mediterranean Sea may account for most of the humidity (Duffourg and Ducrocq, 2011): this is the case when an anticyclonic flow dominates during the 3-4d preceding the events. However, for HPEs in southern France, Duffourg and Ducrocq (2013) estimated that the evaporation from the Mediterranean represents only about $40 \%$ of the water vapor feeding deep convection. Remote sources may also supply moisture, especially for the most intense HPEs, such as the Atlantic (Pinto et al., 2013; Winschall et al., 2012) or tropical areas (Turato et al., 2004; Chazette et al., 2016), even in the form of atmospheric rivers (Davolio et al., 2020). 
Overall, the Mediterranean Sea is a significant heat and moisture source (Duffourg and Ducrocq, 2011), and air-sea exchanges play a key role during HPEs (Lebeaupin Brossier et al., 2008; Rainaud et al., 2016). These exchanges are particularly intense in fall; they are expressed in terms of turbulent fluxes of heat, moisture, and momentum and are controlled by the gradients of temperature, humidity, and wind velocity, respectively, at the air-sea interface. The air-sea interactions can modify the low-level atmospheric stability and notably impact the flow regime and the location and intensity of convergence features and of atmospheric convection and precipitation (e.g., Homar et al., 2003; Xie et al., 2005; Rainaud et al., 2017); thus, SST values and patterns can influence the structure and organization of precipitation systems and their life cycle, severity, propagation speed, and track (Cassola et al., 2016; Bouin et al., 2017; Stocchi and Davolio, 2017). Additionally, ocean waves may significantly impact the roughness length and thus the momentum fluxes and the low-level dynamics of the atmosphere, influencing the atmospheric planetary boundary layer (PBL) and the localization of HPEs (Thevenot et al., 2016).

The mechanisms of HPEs for the three target areas are described below, highlighting the contribution of the HyMeX IOPs to their better understanding.

\section{HPEs over the Italian target areas: outcomes from HyMeX}

\subsection{Northeastern Italy}

The presence of a pronounced trough or a cyclone over the WMED, approaching the Italian peninsula from the west, is the typical atmospheric configuration responsible for most HPEs over the northeastern Italian area during fall; this configuration is associated with intense low-level southeasterly flow over the Adriatic Sea (sirocco), which conveys moisture towards the Alps (Manzato et al., 2015). IOPs 18 and 19 were both characterized by such a large-scale pattern and, together with IOPs 2 and 13, also highlighted another interesting dynamical local process in the area. In fact, when the mesoscale setup described above is established, an easterlynortheasterly flow appears over the eastern Po Valley, just ahead of the Alpine reliefs, resulting from the deflection of the southeasterly low-level jet by the orography. This barrier wind, which often anticipates severe weather events, was already observed (radiosoundings) and simulated and is a consequence of the low-level blocking of the incoming southeasterly flow from the Adriatic, enhanced by the presence of cold air over the plain resulting from nocturnal radiative cooling (Buzzi, 2005; Buzzi et al., 2020b). On some occasions (Monai et al., 2006; Davolio et al., 2009), but not during HyMeX IOPs, a weak bora wind may develop and temporarily reinforce the barrier flow, especially when the driving cyclone/trough moves southward. Compared to previous stud- ies, the SOP1 campaign allowed us to better and more clearly identify the important role of the barrier flow in triggering heavy precipitation where it converges with the sirocco. This behavior critically depends upon the thermodynamic characteristics of the impinging southerly flow that determines the evolution of the convergence pattern, as described in detail in the following.

On the one hand, when a blocked-flow situation persists, low-level convergence occurs well upstream of the orography (Fig. 3a). When the incoming marine flow is conditionally unstable, deep convection ("Upstream" HPEs in Davolio et al., 2016), even in the form of mesoscale convective systems (Davolio et al., 2009; Ricchi et al., 2021) and supercells (Manzato et al., 2015; Miglietta et al., 2016), may develop, which produce heavy rainfall and hail over the plain, even close to the coastal areas (Manzato et al., 2020). In this category of persisting blocked-flow conditions (e.g., IOP18), characterized by low values of the Froude number $U / N h$ (where $U$ is the wind speed, $N$ the upstream Brunt-Väisälä frequency, and $h$ the mountain height; Rotunno and Ferretti, 2001; Miglietta and Rotunno, 2005, 2006), other parameters defined by the vertical profile provide an indication of the possible evolution and severity of the event. In agreement with idealized numerical experiments (Miglietta and Rotunno, 2009, 2010), convection is triggered when the level of free convection (LFC) is located at a low altitude, so that the uplift of the sirocco over the barrier wind, in correspondence to the convergence, is sufficient to overcome it. Consequently, the sirocco does not penetrate inland but begins to feed the convective precipitation systems upstream. Therefore, the ratio between the depth of the cold-air layer and the LFC is indicative of the possible triggering of convection over the plain (Davolio et al., 2016).

On the other hand, the HPEs affecting the northeastern Alps - "Alpine" HPEs described and analyzed in Davolio et al. (2016) and Stocchi and Davolio (2017) - were provoked by the transition from a "flow-around" to a "flowover" regime following the intensification of the sirocco, which progressively penetrates inland, removes the barrier wind (and the convergence), and rises over the orography (Fig. 3b). This evolution is generally favored by a nearly moist neutral profile in the low levels and is characterized by high values of the Froude number. Convection is inhibited upstream of the Alps, but once the moisture-laden flow is lifted over the mountains, convection can be triggered, embedded within the stratiform orographic precipitation and locally increasing its overall intensity. Long-lasting events of this type are often characterized by extreme rainfall amounts, as was IOP19 and the infamous October 2018 Vaia storm (Cavaleri et al., 2019; Davolio et al., 2020; Giovannini et al., 2021).

The latter types of events received a lot of attention and were widely investigated in the last decades in several projects and field campaigns (MAP, Bougeault et al., 2001, among others). Being mainly characterized by strong synop- 

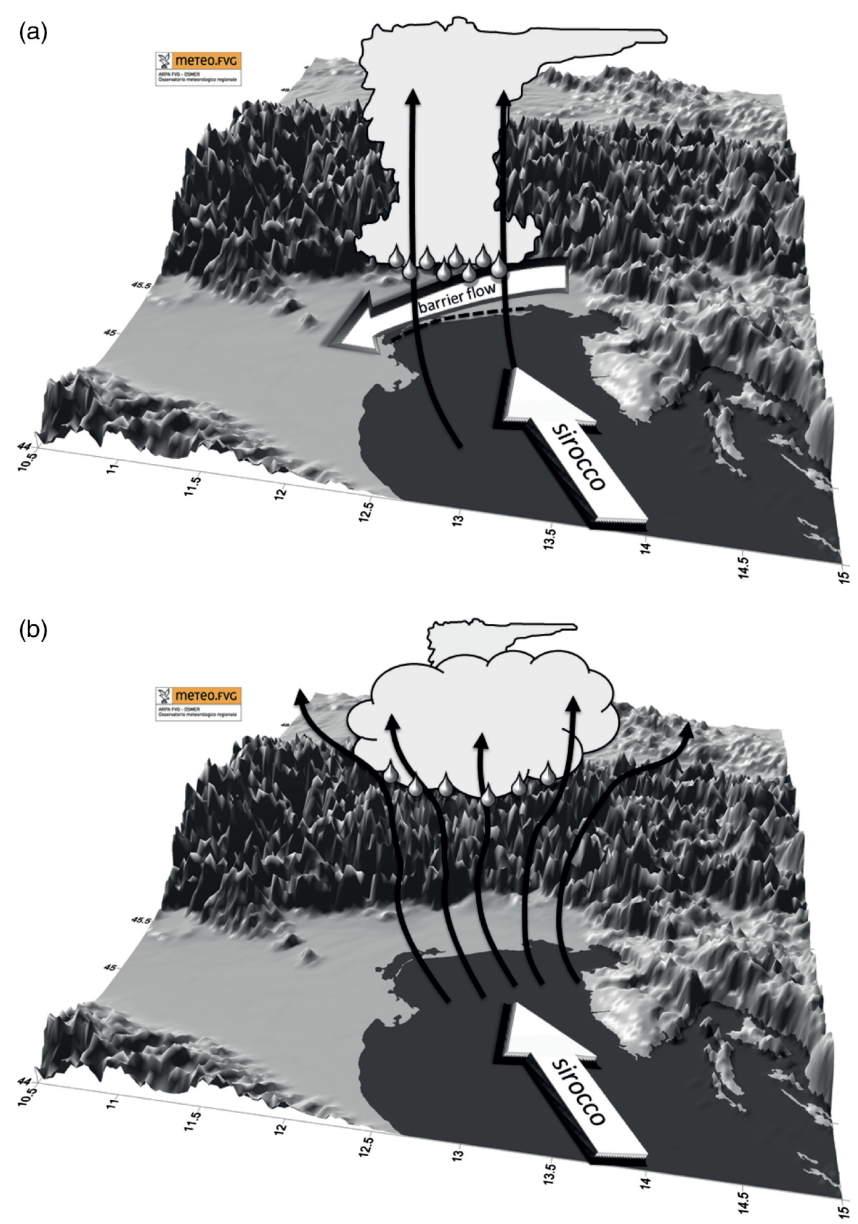

Figure 3. Schematic diagram of the key mechanisms responsible for the two different precipitation patterns over NEI. (a) Upstream event: blocked low-level flow, barrier wind, convergence and deep convection development occurring over the plain, upstream of the orography. (b) Alpine event: unblocked low-level flow, flowover conditions, orographic lifting, and precipitation over the Alps with possible embedded convection (from Davolio et al., 2016).

tic and orographic forcing, these events benefit from a relatively higher predictability (Grazzini et al., 2007; Cavaleri et al., 2019). Conversely, when convection takes place, the interaction of small-scale convective and turbulent processes strongly limits the model prediction capability, since the intrinsic predictability hardly exceeds the timescale of a few hours or even less. However, the mesoscale organization of the flow, as in the presence of a convergence line that triggers convection, may account for a somewhat extended range of predictability with respect to spontaneous isolated convection (Buzzi et al., 2014).

Therefore, most of the research efforts in HyMeX were devoted to a better understanding of convective episodes in order to finally improve their forecast accuracy or at least to increase the awareness of the processes that anticipate the possible development of severe weather systems. In this frame- work, the Friuli Venezia Giulia (FVG) region is a suitable natural laboratory, since it does not only display the highest peak in the average yearly rainfall in the Alpine region (Isotta et al., 2014), but also a high frequency of severe convective episodes such as thunderstorms (Feudale and Manzato, 2014; Pucillo et al., 2020), hailstorms (Manzato, 2012; Punge et al., 2014), tornadoes and waterspouts (Giaiotti et al., 2007), and bow echoes (Pucillo and Manzato, 2010).

IOP2 allowed a detailed study of two intense convective systems evolving into a supercell (Ferretti et al., 2014; Manzato et al., 2015; Miglietta et al., 2016) over the northeastern plain. A synoptic trough determined diffluent flow in the middle troposphere over NEI (a common worldwide condition favoring HPEs; see Pontrelli et al., 1999, and Lin et al., 2001) and drove a very warm and moist southeasterly lowlevel jet stream from the Adriatic. The presence of low equivalent potential temperature $\left(\theta_{\mathrm{e}}\right)$ air aloft determined potential instability in the eastern Po Valley, with values of CAPE well above the average for the period. The characteristic convergence pattern previously described was enhanced by an additional relatively dry southwesterly wind over the Italian northern Adriatic coast originating as downslope Apennines foehn. Moreover, the presence of a shallow low-pressure system over the Venice lagoon maintained the high- $\theta_{\mathrm{e}}$ low-level flow from the sea in the vicinity of the foothills, where convection was triggered, for many hours (Fig. 4). The correct simulation of the storm evolution turned out to be critically dependent on the intensity of this small-scale cyclone and on the low values (but greater than zero) of convective inhibition: both features were necessary to allow the release of convection only near the foothills (Miglietta et al., 2016). The evolution of the mesoscale convergence features controlled the displacement of the supercell in a way qualitatively different from the classical supercell conceptual model developed for the US Great Plains, which are characterized by more homogeneous and stationary conditions (Rotunno and Klemp, 1985).

SOP1 activities also allowed us to exploit the synergy between modeling simulations and monitoring facilities, showing the capability of detecting and simulating important features of convective storms, useful also in operational applications. For example, in IOP2 the Doppler radar identified a mesocyclonic circulation, suggestive of supercell development, in agreement with numerical simulations. Following a phase of complex interaction between two storms (Miglietta et al., 2016), one cell evolved into an arc-shaped echo in the VMI (vertical maximum intensity) radar field (Fig. 5), in agreement with the expected theoretical evolution of an extensive downburst into a bow-echo-like structure (Fujita, 1978). Similar evolutions over the area, sustained by strong cold-air rear inflow, have recently been reported in other episodes of severe convection in the region (Pucillo et al., 2020). Hence, a common mechanism for the intensification of deep convection emerges, occurring when the warm and moist air near the Venice lagoon and the northern Adriatic 


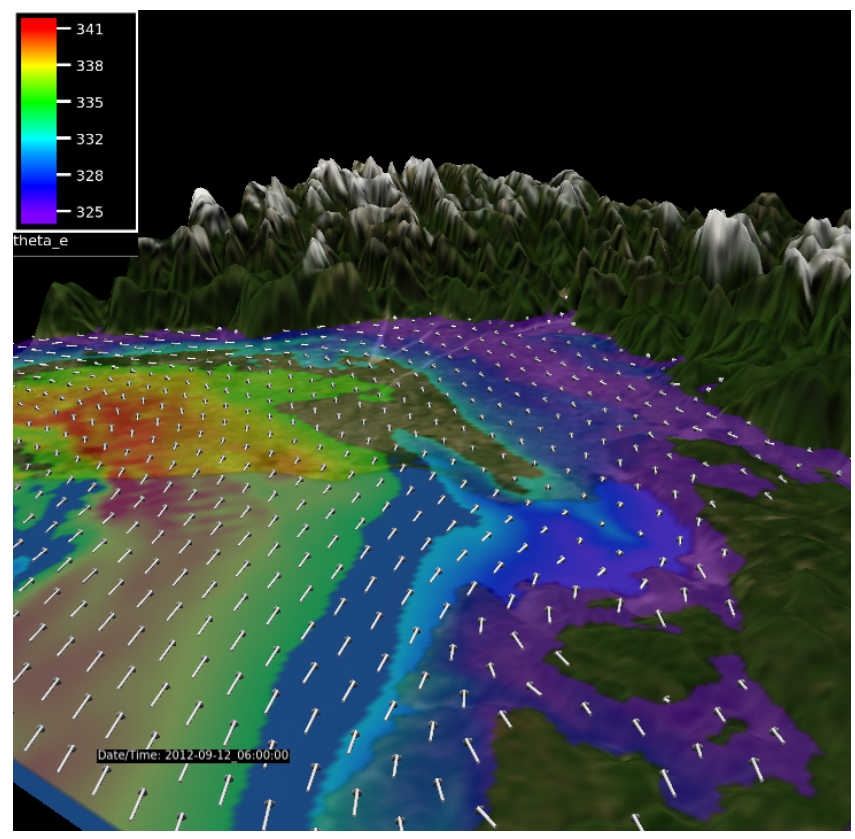

Figure 4. Wind vectors at $350 \mathrm{~m}$ height (white arrows) and $\theta_{\mathrm{e}}$ at $300 \mathrm{~m}$ (shaded) at 06:00 UTC, 12 September 2012 (IOP 2), from a Weather Research and Forecasting (WRF) model run initialized with the Global Forecasting System (GFS) analysis at 12:00 UTC, 11 September. Fields are shown in the innermost parts $(1 \mathrm{~km}$ grid spacing) of the three domains used (from Miglietta et al., 2016).

Sea contrasts with the cooler air behind a small cold frontal system moving eastward.

As described in Sect. 2, one of the main results of HyMeX concerns the identification of the evaporative cold pool under an MCS as one of its key development mechanisms. This feature has been shown for many systems triggered over the sea or close to the coast in other areas (Lee et al., 2016, 2018; Duffourg et al., 2016; Bouin et al., 2017), where the interaction of the cold pool with the incoming moist flow is essential for the subsequent triggering of convection and determines the evolution of the MCS. In contrast, over NEI, where high $-\theta_{\mathrm{e}}$ low-level flow is channeled along the Adriatic towards the Alps, the cold pool can slightly modify the propagation and position of convection, but it does not determine the stationarity of the systems, for which the primary mechanism is the persistent convergence of the low-level jet with the cold barrier wind in blocked-flow conditions (Davolio et al., 2016). Only in the case of supercell development does the cold pool on the forward flank determine the movement of the system as well as the baroclinic generation of vorticity along the cold-air boundary and its intrinsic low-level rotation (Rotunno and Klemp, 1985).

Finally, Miglietta et al. (2016) showed that the low-level cold air trapped in the narrow Alpine valleys can be crucial for limiting the northward extent of the warm-air tongue. Due to their relatively coarse resolution, global analyses/forecasts often miss this feature, possibly leading to the significant climatological underestimation of the rainfall simulated by ECMWF forecasts in the FVG plain and coastal area during summer (Manzato et al., 2016). In turn, the presence of coldair damming may easily be missed or misrepresented in the initial condition of mesoscale models, too.

\subsection{Liguria and Tuscany}

A gridded climatology for Italy has recently confirmed that LT is one of the wettest regions in the peninsula, second only to the northeastern Alpine area (e.g., Fig. 12 in Crespi et al., 2018). Precipitation affects mainly the Liguria region and the northern part of Tuscany, characterized by the highest and steepest orography. The region is prone to severe floods, as demonstrated by the large number of HPEs in the recent past that produced significant damages (Buzzi et al., 2014; Davolio et al., 2015b; Cassola et al., 2016; Silvestro et al., 2016; Fiori et al., 2017). This is due to its peculiar topographical characteristics (steep concave-shaped orography that reaches high elevations within a few kilometers from the coast) that make it exposed to southerly moist flow, impinging on the region in the form of low-level jets, sometimes as atmospheric rivers (Davolio et al., 2020) or warm conveyor belts (Bertò et al., 2004). Without covering all the possible types of HPEs affecting the LT area, HyMeX outcomes and subsequent studies identified and focused on two separate classes of events:

- intense orographically enhanced precipitation over the Apennines;

- MCS formation over the sea or close to the coast, which includes a large portion of severe weather episodes and represents a serious threat to the region.

Each class presents some typical recurring features, and both share most of the large- to meso-scale ingredients necessary to generate persistent rainfall that may evolve into a devastating flood in a few hours.

The occurrence of HPEs in the area is due to a combination of processes at different scales. On the synoptic scale, a slowly advancing baroclinic disturbance associated with an upper-level diffluent trough over the WMED and an upper PV maximum are known as necessary (but not sufficient) ingredients for heavy precipitation (Nuissier et al., 2011). Sometimes, orographic cyclogenesis in the lee of the Alps (Buzzi et al., 2020a) plays a role too. In common with other coastal areas of the WMED, the slowly evolving large-scale circulation favors, at the mesoscale, the persistence of frontal features and of a low-level moist and conditionally unstable airflow directed towards the coastal mountains, whose vertical humidity profile is critical for the persistence of torrential rain in a specific area (Duffourg et al., 2018; Lee et al., 2018). However, the most recent research focused on meso- $\beta$ and meso- $\gamma$-scale processes (typical of density current dynam- 

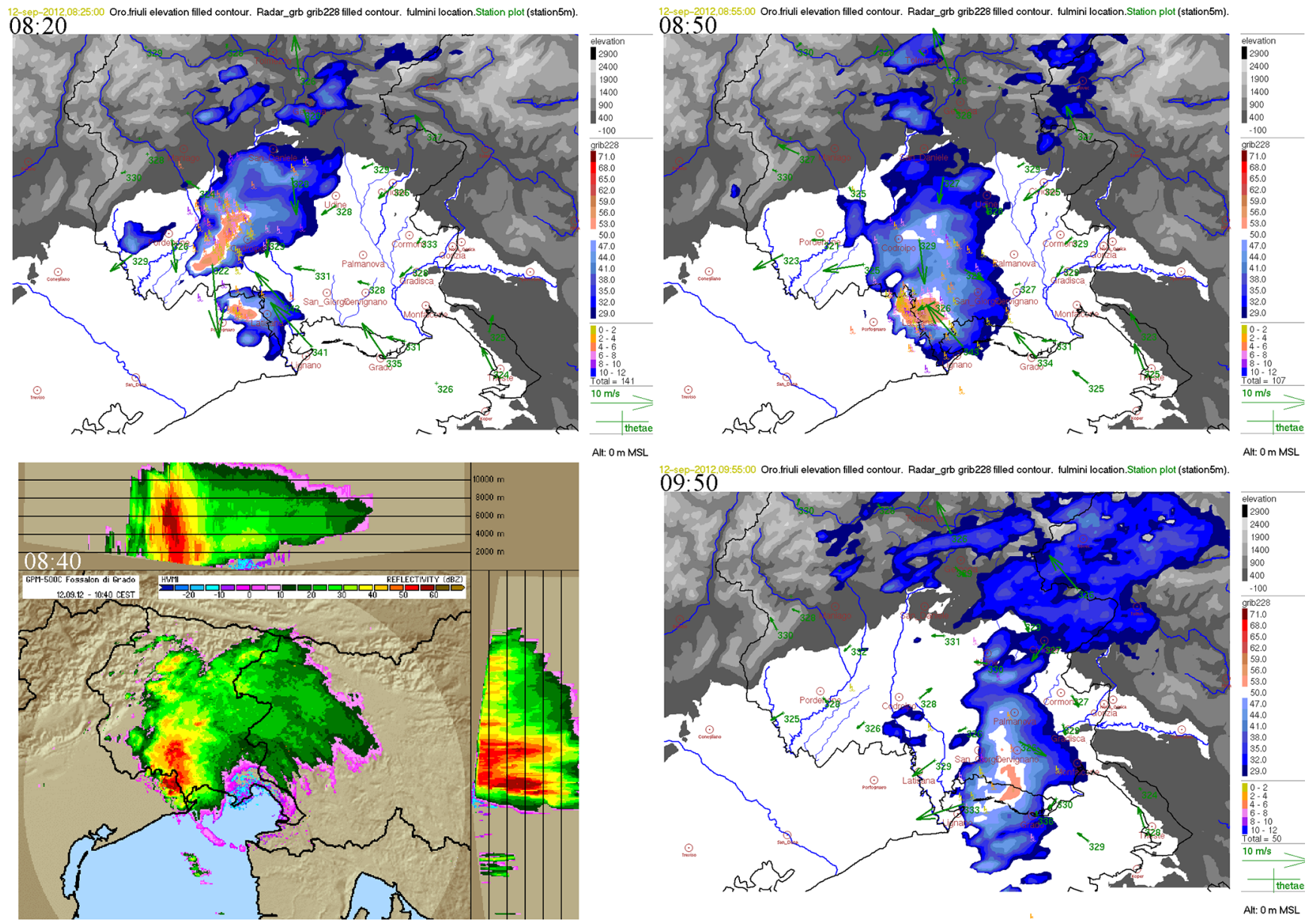

Figure 5. Vertical maximum intensity (VMI) of the reflectivity measured by the Fossalon di Grado radar, with $\theta_{\mathrm{e}}$ (red-blue color bar in dBZ) and $10 \mathrm{~m}$ wind observed by surface stations ( $5 \mathrm{~min}$ time resolution) and CESI-Sirf cloud-to-ground lightnings within the $\pm 6 \mathrm{~min}$ interval (lower color bar shows time delay in minutes) at 08:20, 08:50, and 09:50 UTC, 12 September 2012; bottom left: Fossalon radar maximum reflectivity at 08:40 UTC VMI and lateral projections (horizontal vertical maximum intensity - HVMI) (reprinted from Atmospheric Research, 153, Manzato et al., 2015. 12 September 2012: A supercell outbreak in NE Italy?, 98-118, (C Elsevier 2015, with permission).

ics and convective-scale self-organization), whose prediction and knowledge are affected by greater uncertainties.

Quasi-stationary V-shaped MCSs have been mainly studied, considering that they were responsible for some of the worst floods in the last century (Silvestro et al., 2012, 2016). High-resolution modeling studies, supplemented by available observations, have identified the peculiar dynamical process responsible for the triggering of convection, i.e., the convergence of two low-level currents over the Gulf of Genoa (Buzzi et al., 2014; Fiori et al., 2014). On the one hand, a high CAPE, moisture-laden southerly low-level jet channels between Corsica and the Tuscan coast; on the other hand, a low-level flow of cold and dense air spills through the lowest gaps of the Apennines in the central part of Liguria and propagates southward as a density current over the Gulf of Genoa (Fig. 6). The latter flow originates from pre-existing cold air in the western Po Valley, drawn towards the sea by an ongoing pressure drop; once it reaches the coastline, its thick- ness does not exceed $1 \mathrm{~km}$, becoming progressively thinner as it moves offshore (Fiori et al., 2017). The convergence produces an uplift of the low-level moist air, sufficient to overcome the LFC and thus allow the release of convective energy (Fiori et al., 2014; Davolio et al., 2015b). This kinematic interaction was suggested and somehow observed through airborne and ground-based radar observations already during the MAP field campaign in 1999 (Bousquet and Smull, 2003), but modeling and monitoring tools available at the time were not yet suitable for the recognition of the smallscale features described above. Once the MCS has formed and convection has fully developed, the downdrafts can interact and reinforce the pre-existing low-level cold flow. The equilibrium between the intensity of the cold outflow and the southerly jet and the instability of the air transported by the jet determine the exact evolution of the precipitation system and the location and duration of the rainfall event. 


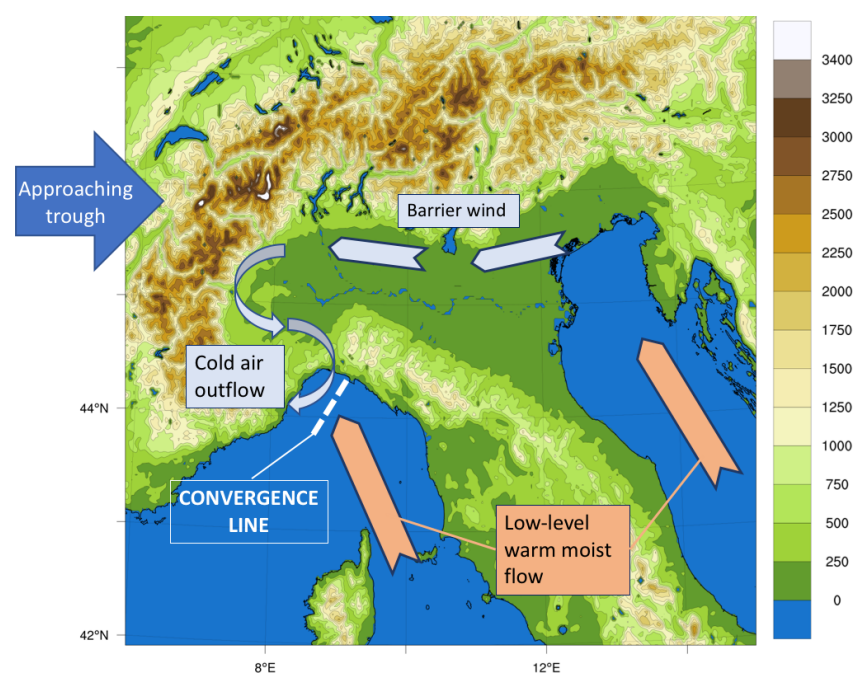

Figure 6. Sketch of the mechanisms responsible for the triggering of quasi-stationary MCSs over the Gulf of Genoa.

Of course, the correct quantitative precipitation forecast (QPF) strongly depends on the ability of the model to represent the cold-air outflow from the Po Valley and the convergence setup (Buzzi et al., 2014). Consequently, the NWP spatial resolution becomes an important factor (Davolio et al., 2015b; Fiori et al., 2017), because it allows us to describe with precision not only the convective system dynamics, but also the orographic features (Bassi, 2014) and in turn the propagation of the density current responsible for the convergence line. Buzzi et al. (2014) concluded that the crucial role played by such a mesoscale setting can explain the extended range of predictability of these events with respect to the typical timescale of isolated and spontaneous convection. Although this convergence pattern does not ensure that heavy precipitation occurs, it has certainly become a warning sign for weather forecasters in recent years.

A well-observed example of these kinds of events was monitored during IOP16a. One of the several MCSs developed in the northern part of the WMED (Duffourg et al., 2016) was triggered over the eastern Ligurian coast because of low-level convergence. The pre-frontal MCS remained quasi-stationary during the morning, producing precipitation amounts reaching $250 \mathrm{~mm}$ in $24 \mathrm{~h}$ and up to $50 \mathrm{~mm}$ in $1 \mathrm{~h}$, that were responsible for local floods. Nuissier et al. (2016) confirmed the important role played by the low-level convergence using two convection-permitting ensemble systems, showing that it is a key factor controlling the predictability of HPEs over the Liguria region.

An additional important first-time confirmation of this dynamical mechanism was provided by the dropsonde data during the last IOP of SOP1. In fact, during IOP19, two dropsondes were deployed during the Falcon flight respectively over the western and eastern parts of the Gulf of Genoa (Fig. 7). While the latter recorded southerly to southwesterly flow all along the profile, the former revealed a sharp low-level thermal inversion, below $900 \mathrm{hPa}$, associated with the presence of a northerly, stably stratified flow advecting cooler air from the Po Valley.

However, during IOP19 convection did not develop over the sea, despite the presence of low-level convergence. Instead, intense orographic precipitation occurred over the Apennines between Liguria and Tuscany, fed by intense southwesterly flow induced by a cyclone over the Gulf of Lyon. Therefore, in this case the role of the orography was two-fold. On the one hand, it modulated the gap flow directed southward over the sea, which restrained the southerly inflow in the eastern portion of the Gulf of Genoa and produced local convergence; on the other hand, it produced the uplift of the humid impinging flow. Both forcings were critical in determining the location and intensity of heavy rainfall and were generally well reproduced by high-resolution models (Ferretti et al., 2014). Orographic precipitation also occurred during IOP7b and IOP16c but was associated with embedded convection (as revealed by lightning data) that enhanced the rainfall intensity at the orographic divide. These mechanisms were already thoroughly studied in the past (e.g., Rotunno and Houze, 2007); however, in the context of HyMeX, it was possible to show that high-resolution, convection-permitting models provide a useful guidance for forecasters and that their performance clearly improves as grid spacing decreases (Bassi, 2014; Ferretti et al., 2014; Davolio et al., 2015b; Barthlott and Davolio, 2016).

The relevant dynamical aspects that affect the heavy precipitation over LT are due not only to the orography of the region, which provides the direct uplift or blocking (Alps and Apennines), but also to the main upstream islands (Sardinia and Corsica). In IOP13, Barthlott and Davolio (2016) showed that the two islands can significantly perturb the lowlevel wind, temperature, and humidity fields. Thus, the flow deviations (due to blocking, flow splitting, and channeling effects between the islands) and local circulations (including drainage flows, land and sea breeze systems) determine either patterns of convergence over the sea upstream of the Italian coast, where convection is triggered, or the exact location where the deflected flow interacts with the orography inland. Moreover, the offshore night convection around Corsica modifies the conditions upstream of Tuscany and may affect precipitation there (Barthlott et al., 2016).

The feedbacks between convective-scale motions and orographic flows can, however, be very complex; hence, it is not straightforward to trace back the observed HPEs to theoretical studies in idealized conditions, such as Miglietta and Rotunno (2014) or Kirshbaum et al. (2019). Case study analysis may highlight important physical aspects or point out predictability/forecasting issues. During SOP1, the development of convection between the Apennines and the Po Valley was analyzed in Pichelli et al. (2017), comparing IOP6 and IOP13. In both cases an eastward-moving trough (and front) induced organized convection in the region; however, 

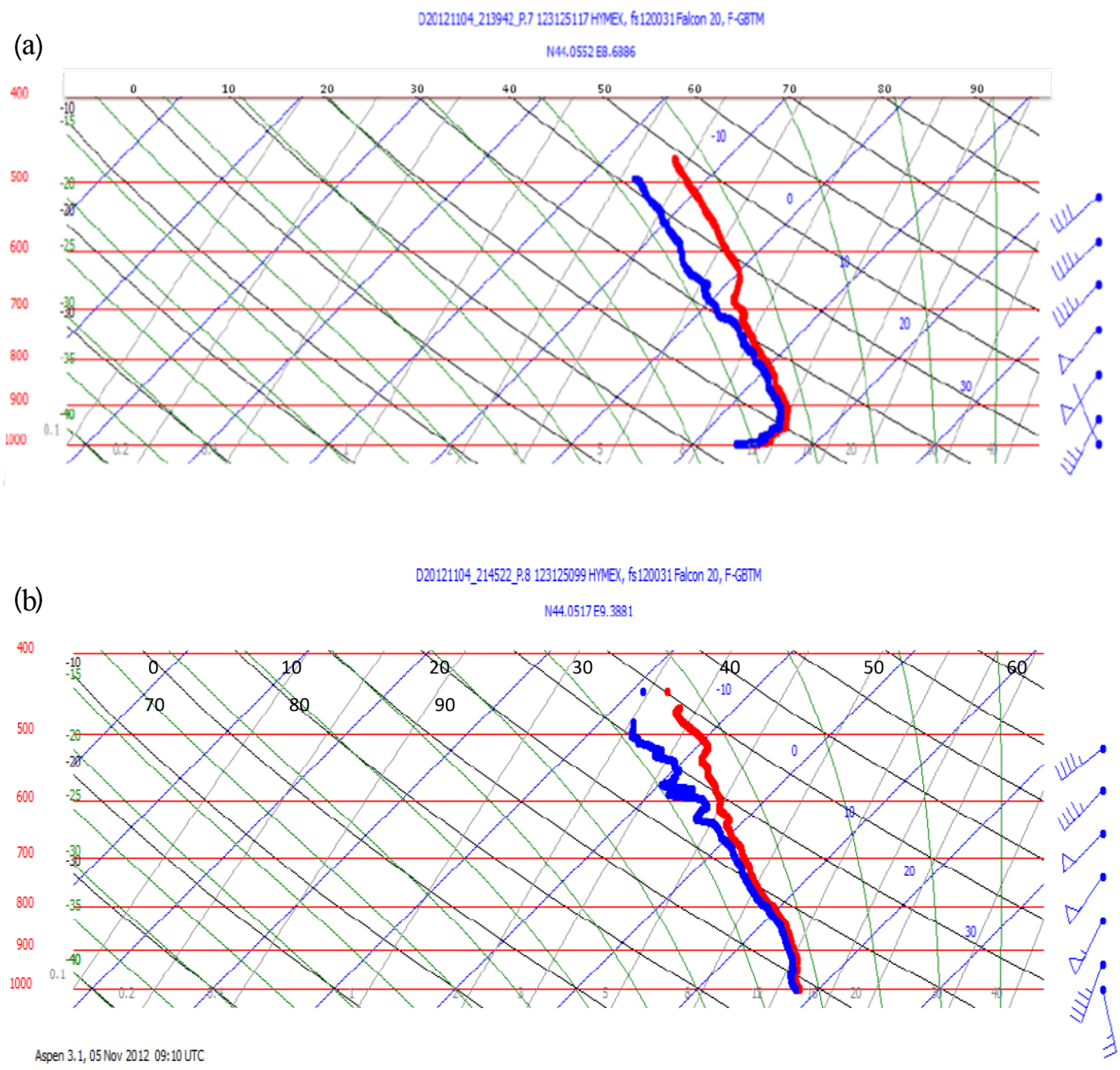

Figure 7. Vertical profile from the two dropsondes deployed by the Falcon flight over the Gulf of Genoa at (a) DS1 (44.055 ${ }^{\circ}$ N, $8.689^{\circ}$ E) at 21:40 UTC and (b) DS2 $\left(44.052^{\circ} \mathrm{N}, 9.388^{\circ} \mathrm{E}\right)$ at 21:45 UTC, 4 November 2012. Courtesy of Julien Delanoe (LATMOS/IPSL/UVSQ, France) (from Ferretti et al., 2014).

the slightly different characteristics of the meridional winds across and ahead of the front determined a delicate balance between the competing mechanisms of orographic subsidence on the leeward side of the Apennines and frontal uplift in the Po Valley, responsible for the different degree of predictability of the two cases. In particular, for IOP13, the "flow-around" regime contributed to low-level convergence in the Alpine concavity; for IOP6, the flow upstream was at the threshold between "flow-over" and "flow-around" regimes, and hence downstream convection was very sensitive to small differences in the simulated environmental parameters.

Rainaud et al. (2016) found that, in the whole SOP1, although some HPEs occurred without significant air-sea fluxes, all strong air-sea exchange events occurred during or
1-2 d before an HPE. IOP13 allowed us to show how air-sea exchanges, even in areas relatively far in the Mediterranean or even a few days in advance, may play a key role for HPEs over LT. A persistent southwesterly flow within the marine boundary layer transported moisture towards the French and Italian coasts from the western Mediterranean, feeding a few convective systems. The same moisture was extracted by the dry and strong mistral over the Gulf of Lyon 1-2 d before and advected near the periphery of the Mediterranean (see Figs. 13 and 14 in Rainaud et al., 2016). This means that there can be a connection between apparently independent severe weather events which manifests itself through air-sea interaction processes. Caldas-Alvarez and Khodayar (2020), assimilating GPS-derived zenith total delay (GPS-ZTD) data in sensitivity experiments for IOP16a, showed that the resid- 
ual moisture of a previous HPE may be transported by a large-scale front and contribute to precipitation together with evaporation from the Mediterranean and northern Africa.

\subsection{Central Italy}

The CI hydrometeorological site is in a peculiar position, being surrounded by the sea on both sides, i.e., the Tyrrhenian Sea to the west and the Adriatic Sea to the east. The area is densely populated, mainly because it includes the wide urban area of Rome, with approximately 4 million inhabitants. As with the rest of the peninsula, $\mathrm{CI}$ is characterized by complex orography: moving from the western coast across the region, the elevation grows from sea level to nearly $3000 \mathrm{~m}$ in less than $150 \mathrm{~km}$ and down again further east. The area is characterized by many small- and medium-sized steep and densely urbanized coastal catchments (Lombardi et al., 2021), which display fast response to heavy precipitation and are prone to flash floods.

Two main synoptic patterns may be identified as favorable to heavy rainfall over CI. They are associated with precipitation systems affecting either the western side or eastern side, fed by moist low-level currents flowing over the Tyrrhenian Sea or Adriatic Sea, respectively.

- In the first category, an upper-level trough (sometimes associated with an orographic cyclone over the Gulf of Genoa) and a cold front approach the Italian peninsula from the west; convective systems are triggered over the sea and subsequently affect CI, as in the case of IOPs 12 and 13 .

- In the second category, the presence of a cut-off low over the Tyrrhenian Sea is responsible for a cyclonic circulation over the central Mediterranean; hence, an intense bora flow is generated over the Adriatic Sea, whose interaction with the Apennines produces intense rainfall, as occurred during IOP4.

Both situations were studied in detail during HyMeX through numerical modeling and many instruments deployed over CI dedicated to the study of the microphysical properties of convective precipitation. In fact, besides the operational network, which comprises more than 200 rain gauges and three C-band radars, X- and K-band radars and also different types of disdrometers were specifically installed for the campaign (details in Ferretti et al., 2014).

IOP13 was characterized by a quite strong synoptic forcing, with an upper-level trough extending toward northern Algeria and moving eastwards towards Corsica and the Tyrrhenian coast. Ahead of the trough, the cold front shifted over the Mediterranean Sea, moving around a low pressure centered over the Gulf of Genoa. A pre-frontal intense warm and moist $\left(\theta_{\mathrm{e}}\right.$ above $\left.330 \mathrm{~K}\right)$ southwesterly airflow between Sicily and Sardinia impinged upon the Tyrrhenian coast; its convergence with westerly winds, blowing at higher latitudes, allowed the triggering and development of an intense

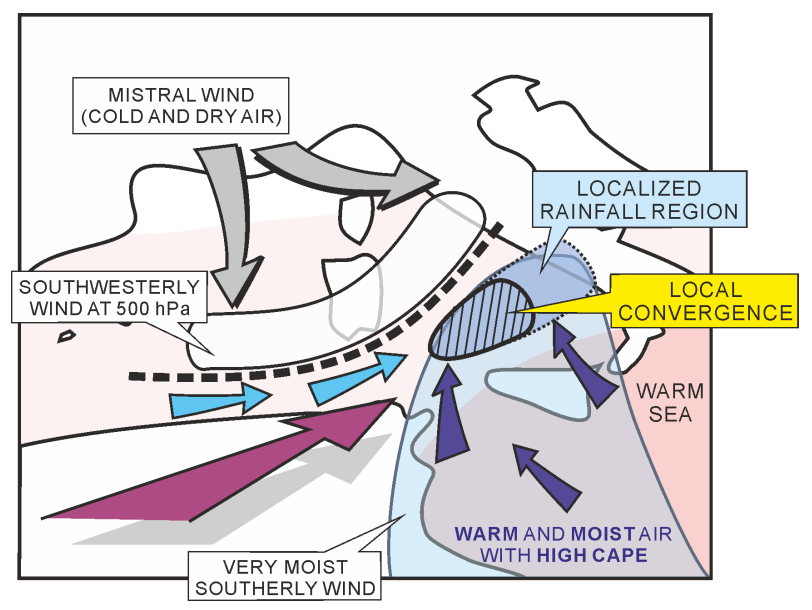

Figure 8. Schematics summarizing the main features and processes responsible for the maintenance of deep convection upstream of southern Italy and leading to HPEs for Period 1 of HyMeX IOP13. Grey arrows indicate the mistral wind behind the edge of the cold front (thick dashed line). The light blue arrows depict the lowlevel westerlies to southwesterlies ahead of the front. Dark blue arrows show the low-level moist southerlies from the eastern Mediterranean encompassed in the blue-shaded area. The purple arrow illustrates the elevated tropical plume. The local low-level convergence is indicated by a hatched area. The rainfall regions are indicated by blue shading within the dotted line (from Lee et al., 2016).

convective line that affected the urban area of Rome. In these conditions, numerical models reproduced quite accurately the convective system, which grew within the warm sector of a Mediterranean cyclone, and the associated intense rainfall. However, the correct simulation of the precipitation systems was dependent on the accurate description of the fine structure of the cyclone (Ferretti et al., 2014).

On the same day, a multi-cell, V-shaped, retrograderegeneration MCS developed over the Tyrrhenian Sea but affected an area slightly to the south of CI. Lee et al. (2016) showed that, besides the low-level convergence over the sea, ahead of the upper-level trough (see their Fig. 11a), and the low-level advection of warm and moist air from the south, the strength of convection was increased by an elevated moisture plume from the tropics that enriched the mid-level humidity content (Fig. 8). Later, a second MCS was triggered by the orography of Algeria and affected Sicily and southern Italy, again maintained by the high low-level moisture content and a marked low-level convergence. In order to improve the simulation skill for the latter MCS, Lee et al. (2016) found that the inclusion of northern Africa in the domain was crucial.

Barthlott and Davolio (2016) concluded that predictability of MCSs is lower for isolated convective systems, as the former, higher when they are directly triggered by the frontal passage, as the latter. They thoroughly analyzed the different phases of IOP13, finding that the low-level flow is crucial for HPEs over CI, while its thermodynamic properties are 
essential for determining its interaction with the orography. In fact, intense precipitation affects the inland regions only if the flow can overcome the Apennines, while an impinging stable flow is deflected to the north along the coast of CI. Consequently, models succeed in forecasting heavy precipitation if they correctly describe the low-level flow characteristics.

Not only the low-level moisture advection towards coastal areas is important, but the total column atmospheric moisture was also identified as a key parameter for convective initiation (Khodayar et al., 2018). The relevance of moisture profiles for HPEs emerged in several IOPs and for different WMED target areas: for instance, during IOP12, heavy precipitation systems developed within an area with maximum integrated water vapor (IWV) of $35-45 \mathrm{~kg} \mathrm{~m}^{-2}$. A sudden increase in IWV of about $10 \mathrm{~kg} \mathrm{~m}^{-2}$ occurred 6-12 $\mathrm{h}$ before the intense events, which received moisture from different sources simultaneously (the transport of humidity was mainly from the Atlantic and from the southern Mediterranean), thus involving transport on different timescales. In particular, the increase in the low-level humidity content strongly impacted stability and convection intensity (Khodayar et al., 2018).

The synergy between the different observation platforms and the lightning detection network allowed us, for the first time in Italy, to simultaneously investigate several aspects of convection such as lightning (LINET network, Betz et al., 2009; Federico et al., 2014; Roberto et al., 2016; Torcasio et al., 2021), raindrop size distributions at the ground (disdrometers), and graupel aloft (radar). Moreover, instruments deployed during SOP1 contributed to a long time series of disdrometer measurements in Rome that allowed us to optimize radar algorithms specifically for the Italian climatology and to improve the estimation of vertical profiles of raindrop size distribution (Adirosi et al., 2016, 2018).

Despite being a relatively small and shallow basin, the Adriatic Sea plays a critical role during HPEs affecting CI. This occurs mainly through air-sea exchanges (Ricchi et al., 2016; Ličer et al., 2016; Davolio et al., 2017), which may be very intense during bora events. The presence of a lowpressure system settled over the central Mediterranean induces cyclonic bora (Horvath et al., 2009) over the northern/central Adriatic basin; the latter is often accompanied by precipitation and gusty winds affecting the eastern side of the CI target area. This was the case with IOP4, which occurred on 14 September 2012, when heavy precipitation (more than $150 \mathrm{~mm}$ in a few hours), mainly along the central Italian coast, caused several river overflows and flooding (Mazzarella et al., 2017). Convective systems in the central Adriatic basin (Fig. 9) were triggered by low-level wind convergence between northeasterly cooler bora and moist and warm southeasterly sirocco and were later advected inland. Furthermore, orographic uplift over the eastern slopes of the Apennines produced stratiform precipitation (Fig. 10).
Balloons and radiosounding observations in L'Aquila indicated a high humidity content in the lowest $6 \mathrm{~km}$ in IOP4 along with a lowering of the tropopause, as shown by the $\mathrm{O}_{3}$ measurements. Such conditions are expected in the case of an intense Mediterranean cyclone close to the area and of intense bora conditions. In addition to the simplistic conceptual model that associates rainfall with the mesoscale circulation around a low-pressure system and with the orographic uplift of moisture, Davolio et al. (2017) showed that the interplay between surface fluxes and orographic effects is complex and basically nonlinear. In fact, heat and moisture exchanges at the Adriatic Sea surface affect the PBL thermodynamic profile and stability, which control the dynamical processes induced by the downstream orography.

- In case of "flow-over", upstream ascending motion produces heavy precipitation along the Apennines slopes and over the crest.

- In case of a blocked-flow regime, flow retardation and deviation are responsible for precipitation localized upstream of the ridge divide (Stocchi and Davolio, 2017).

\section{Summary and conclusions}

The first Special Observation Period of HyMeX was held in fall 2012 and focused on the observation and numerical simulation of HPEs and floods in the northwestern Mediterranean. Nine of the 20 IOPs involved Italy, enabling a unique opportunity for monitoring and analyzing HPEs over the three Italian target areas of NEI, LT, and CI. The present paper provides a review of the main findings that emerged from the HyMeX campaign over Italy, allowing for an improved understanding of the mechanisms responsible for HPEs and for the identification of the most relevant mesoscale features associated with them.

In NEI, the SOP1 campaign allowed us to clarify the important role of the barrier wind, resulting from the blocking of the southeasterly moist and warm low-level flow from the Adriatic, in triggering HPEs. Two main patterns responsible for HPEs were identified, depending on the upstream environmental conditions, in particular static stability and wind speed.

- Upstream events, characterized by low-level blocked flow, barrier wind, convergence, and deep convection over the plain, even well upstream of the orography.

- Alpine events, in which the intensification of the southerly low-level jet progressively erodes the barrier wind and produces an unblocked low-level flow, orographic lifting, and precipitation over the Alps, possibly associated with embedded convection.

The analysis of IOP6 revealed also that the numerical simulation of convection in the Po Valley is particularly sensitive 


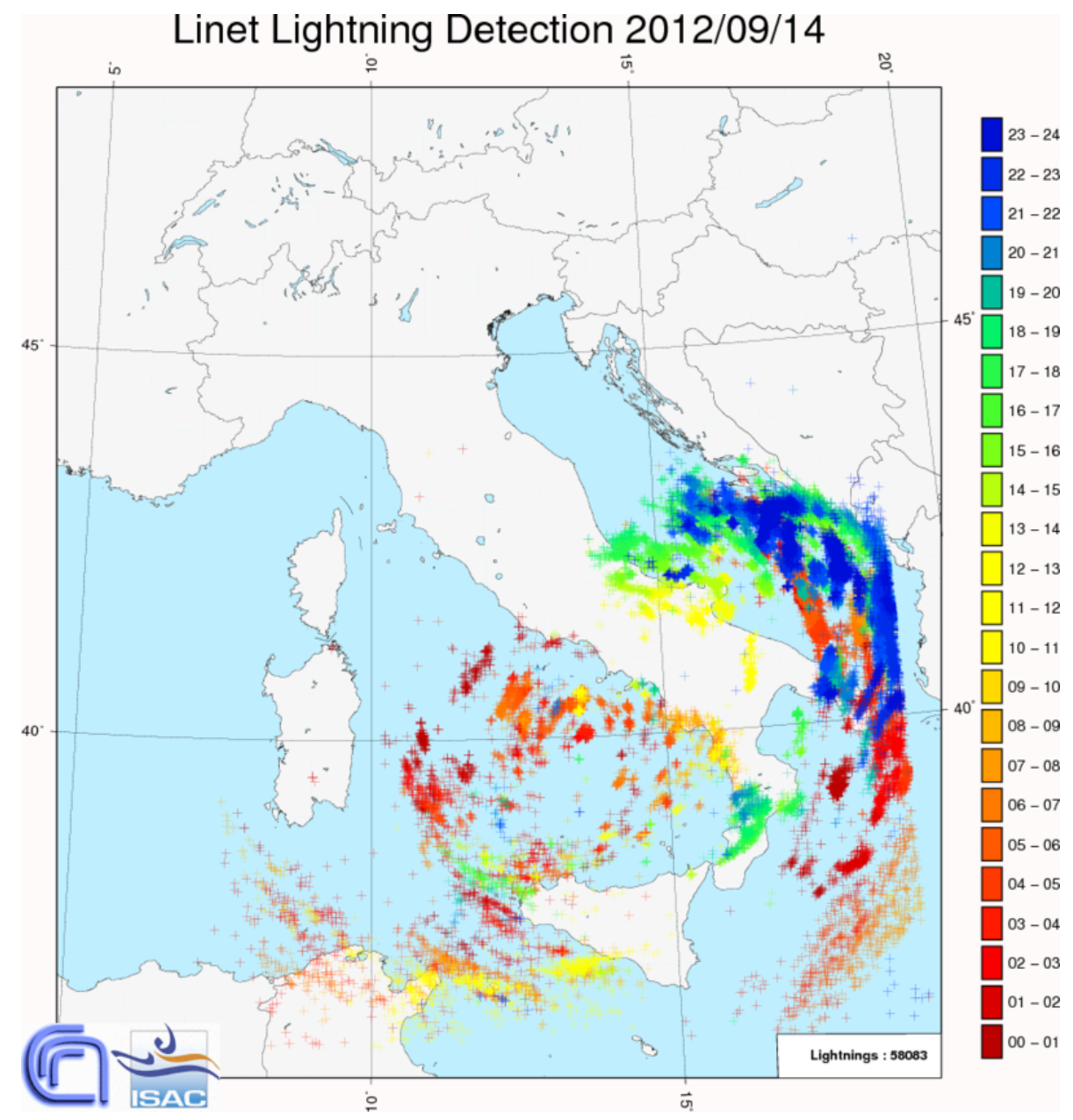

Figure 9. LINET lightning activity measured on 14 September 2012. The map shows the intra-cloud and cloud-to-ground strokes registered in $24 \mathrm{~h}$. Different colors are associated with different hours.

to small changes in the upstream environmental conditions when they are close to the threshold between "flow-over" and "flow-around" regimes (Froude number $\sim 1$ ).

Some typical ingredients conducive to severe convection in the region were identified in IOP2. In particular, a tongue of moist air advected toward the eastern Po Valley and curved westward by a shallow pressure low in the northern Adriatic was found to play a key role in the development of convective storms near the foothills and in their subsequent evolution into small bow-echo-like structures in the coastal areas.

LT is one of the wettest areas of the peninsula, and in the last decade it has been severely affected by a high number of HPEs and disastrous floods, favored by the steep concaveshaped coastal orography exposed to southerly moist lowlevel jets. HyMeX focused on two separate classes of events:

- intense orographically enhanced precipitation over the Apennines;

- quasi-stationary MCSs over the sea or close to the coast.
The latter category, which includes a large part of HPEs in Liguria, was deeply investigated in HyMeX (e.g., IOP16a). Convection is typically triggered by the convergence of two main low-level currents: a persistent moist and conditionally unstable flow channeled between Corsica and the Tuscan coast over the Tyrrhenian Sea and the outflow of cold and dense air, spilling from the Po Valley through the lowest gaps of the Apennines, forced by an ongoing pressure drop, and propagating southward as a density current over the Gulf of Genoa. The latter was clearly identified as a sharp lowlevel inversion in a dropsonde profile over the western side of the Gulf of Genoa during IOP19. The equilibrium between the southerly jet and the intensity of the cold flow, possibly reinforced by convective downdrafts, as well as the instability of the warm air impinging on the cold pool determine the exact evolution of the MCS.

The HPEs over LT are determined not only by the orography of the region, but also by the perturbations induced by Sardinia and Corsica on the environmental parameters. Dynamic forcings and thermally driven circulations may de- 


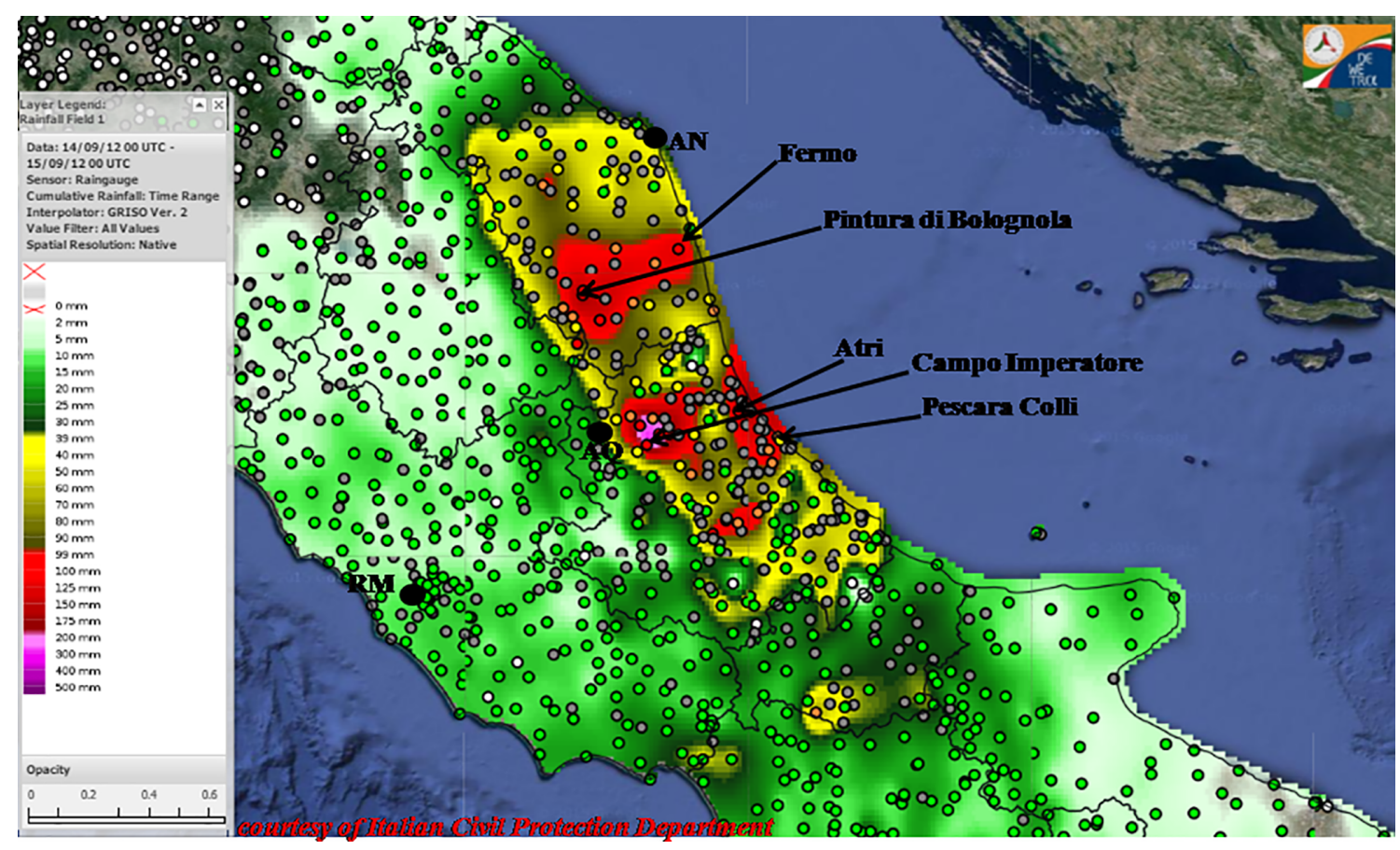

Figure 10. Interpolated map of $24 \mathrm{~h}$ accumulated rainfall from 00:00 UTC on 14 September 2012 over central Italy taken from the DEWETRA system from rain gauge measurements. Black contours are the administrative boundaries of the regions, while the colored circles represent the warning pluviometer thresholds (from Maiello et al., 2017; courtesy of the Italian Department of Civil Protection).

flect the flow, modifying the areas where it interacts with the orography or influencing the convergence patterns upstream of the Italian coasts where convection is triggered.

Finally, two main synoptic configurations were identified for HPEs in the CI target area.

- When an upper-level trough approaches the Italian peninsula from the west, low-level convergence over the sea triggers convective systems that later affect the Tyrrhenian coast, sustained by high low-level moisture content and, possibly, by a mid-level moisture plume from the tropics, as in IOP13.

- When a cut-off low develops over the Tyrrhenian Sea, intense bora blows over the Adriatic Sea and the eastern side of $\mathrm{CI}$ is affected by intense precipitation and gusty winds, as in IOP4. Convective systems develop over the sea, triggered by low-level convergence, while orographic uplift over the eastern slopes of the Apennines produces stratiform orographic precipitation.

The Adriatic Sea plays a critical role in the latter group of HPEs mainly through air-sea exchanges. The interplay between surface fluxes and orographic effects is nonlinear: sea surface exchanges may impact significantly the PBL thermodynamic profile and the stability of the flow impinging on the orography, favoring either "flow-over" and precipitation over the Apennines or "flow-around" and precipitation localized upstream of the ridge.
Many modeling studies agree that the moisture structure in the lower troposphere is a key factor for accurate prediction of precipitation systems in the coastal mountainous region of the northern Mediterranean. In fact, the stratification of the lower troposphere, also affected by air-sea exchanges, determines both the interaction of the flow with the coastal orography and the location where convection is triggered.

In conclusion, the HyMeX SOP1 has allowed us to disentangle some important mesoscale mechanisms conducive to HPEs in the central and northern Italian regions. In the near future, the TEAMx (Serafin et al., 2018) program will further clarify the mechanisms for orographic convection in the Alpine area with a dedicated working group. The planned activities will further improve our understanding of the processes relevant for HPEs in an area that has been the subject of intense investigation in the last 20 years (MAP; Bougeault et al., 2001), but shifting the focus on the meso- $\gamma$-scale processes.

In contrast, HPEs in southern Italy remain the subject of marginal attention in research activities and the scientific literature, although intense precipitation systems are not unusual in the area (Caccamo et al., 2017; Martinotti et al., 2017). Funatsu et al. (2009) found that the arc between Tunisia, Sicily, and southern Italy shows a climatological peak of convective activity in fall and is a prominent area of initiation of MCSs leading to HPEs over southern Italy. Moreover, due to its peculiar hydrography, i.e., short watersheds which are activated only in rainy periods and display 
fast response to precipitation, HPEs may be conducive to flash floods (Senatore et al., 2020; Avolio et al., 2019) even when precipitation is confined in very limited areas (e.g., Gascon et al., 2016). Quasi-stationary low-level convergence patterns (Mastrangelo et al., 2011), deep cyclones generating intense low-level wind associated with orographic uplift or convergence (Moscatello et al., 2008; Marra et al., 2019), and orographic triggering over low obstacles in the presence of high low-level humidity (Miglietta and Regano, 2008) have already been identified as mechanisms potentially conducive to HPEs in southern Italy. Even in the absence of dedicated funding, we hope that the Italian scientific community will be able to devote more attention to this area in the future, supporting the development of regional weather centers (belonging to the Italian Department of Civil Protection) that have been established in southern Italy only recently.

Code and data availability. No data sets were used in this article.

Author contributions. MMM and SD jointly developed the review paper and edited the manuscript.

Competing interests. The contact author has declared that neither they nor their co-authors have any competing interests.

Disclaimer. Publisher's note: Copernicus Publications remains neutral with regard to jurisdictional claims in published maps and institutional affiliations.

Special issue statement. This article is part of the special issue "Hydrological cycle in the Mediterranean (ACP/AMT/GMD/HESS/NHESS/OS inter-journal SI)". It is not associated with a conference.

Acknowledgements. This work is a contribution to the HyMeX program. The authors are grateful to the Department of Civil Protection (DPC) for allowing access to the regional networks of rain gauges, composite radar images, and the DEWETRA visualization platform.

Financial support. This research has been supported by the project "FOE2019: Cambiamento climatico: mitigazione del rischio per uno sviluppo sostenibile" funded by the Italian Ministry of University and Research and by the project "DPC 2020-2021-Accordo DPC/CNR-ISAC" funded by the Italian Department of Civil Protection.

Review statement. This paper was edited by Alberto Guadagnini and reviewed by two anonymous referees.

\section{References}

Adirosi, E., Baldini, L., Roberto, N., Gatlin, P., and Tokay, A.: Improvement of vertical profiles of raindrop size distribution from micro rain radar using $2 \mathrm{D}$ video disdrometer measurements, Atmos. Res., 169B, 404-415, 2016.

Adirosi, E., Nicoletta, R., Montopoli, M., Gorgucci, E., and Baldini, L.: Influence of disdrometer type on weather radar algorithms from measured DSD: Application to Italian climatology, Atmosphere, 9, 360, https://doi.org/10.3390/atmos9090360, 2018.

Adler, B., Kalthoff, N., Kohler, M., Handwerker, J., Wieser, A., Corsmeier, U., Kottmeier, C., Lambert, D., and Bock, O.: The variability of water vapour and pre-convective conditions over the mountainous island of Corsica, Q. J. Roy. Meteor. Soc., 142, 335-346, 2016.

Avolio, E., Cavalcanti, O., Furnari, L., Senatore, A., and Mendicino, G.: Brief communication: Preliminary hydro-meteorological analysis of the flash flood of 20 August 2018 in Raganello Gorge, southern Italy, Nat. Hazards Earth Syst. Sci., 19, 1619-1627, https://doi.org/10.5194/nhess-19-1619-2019, 2019.

Barthlott, C. and Kirshbaum, D. J.: Sensitivity of deep convection to terrain forcing over Mediterranean islands, Q. J. Roy. Meteor. Soc., 139, 1762-1779, https://doi.org/10.1002/qj.2089, 2013.

Barthlott, C. and Davolio, S.: Mechanisms initiating heavy precipitation over Italy during the HyMeX Special Observation Period 1: A numerical case study using two mesoscale models, Q. J. Roy. Meteor. Soc., 142, 238-258, https://doi.org/10.1002/qj.2630, 2016.

Barthlott, C., Adler, B., Kalthoff, N., Handwerker, J., Kohler, M. and Wieser, A.: The role of Corsica in initiating nocturnal offshore convection, Q. J. Roy. Meteor. Soc., 142, 222-237, 2016.

Bassi, C.: Modelli meteorologici ad alta risoluzione: simulazione di episodi di precipitazione intensa in Liguria e Toscana durante la campagna HyMeX, Università di Milano, available at: https://www.sba.unimi.it/en/thesis/49.html (last access: 4 February 2022), 2014.

Bertò, A., Buzzi, A., and Zardi, D.: Back-tracking water vapour contributing to a precipitation event over Trentino: A case study, Meteorol. Z., 13, 189-200, https://doi.org/10.1127/09412948/2004/0013-0189, 2004.

Betz, H.-D., Schmidt, K., Laroche, P., Blanche, P., Oettinger, W. P., Defer, E., Dziewit, Z., and Konarski, J.: LINET - an international lightning detection network in Europe, Atmos. Res., 91, 564573, 2009.

Bock, O., Bosser, P., Pacione, R., Nuret, M., Fourrié, N., and Parracho, A.: A high-quality reprocessed ground-based GPS dataset for atmospheric process studies, radiosonde and model evalu ation, and reanalysis of HyMeX Special Observing Period, Q. J. Roy. Meteor. Soc., 142, 56-71, https://doi.org/10.1002/qj.2701, 2016.

Bougeault, P., Binder, P., Buzzi, A., Dirks, R., Houze, R., Kuettner, J., Smith, R. B., Steinacker, R., and Volkert, H.: The MAP Special Observing Period, B. Am. Meteorol. Soc., 82, 433-462, 2001.

Bouin, M.-N., Redelsperger, J.-L., and Lebeaupin Brossier, C.: Processes leading to deep convection and sensitivity to sea-state representation during HyMeX IOP8 heavy precipitation event, Q. J. Roy. Meteor. Soc., 143, 2600-2615, https://doi.org/10.1002/qj.3111, 2017. 
Bresson, E., Ducrocq, V., Nuissier, O., Ricard, D., and de SaintAubin, C.: Idealized numerical simulations of quasi-stationary convective systems over the northwestern Mediterranean complex terrain, Q. J. Roy. Meteor. Soc., 138, 1751-1763, 2012.

Bousquet., O. and Smull, B. F.: Observations and impacts of upstream blocking during a widespread orographic precipitation event, Q. J. Roy. Meteor. Soc., 129, 391-409, 2003.

Buzzi, A.: Heavy precipitation and Alpine orography, Proc. of the International Workshop on timely warnings of heavy precipitation episodes and flash floods, Ljubljana, Slovenia, 21-22 October 2004, 12 pp., 2005.

Buzzi, A. and Alberoni, P. P.: Analysis and numerical modelling of a frontal passage associated with thunderstorm development over the Po Valley and the Adriatic Sea, Meteorol. Atmos. Phys., 48, 205-224, 1992.

Buzzi, A. and Foschini, L.: Mesoscale Meteorological Features Associated with Heavy Precipitation in the Southern Alpine Region, Meteorol. Atmos. Phys., 72, 131-146, https://doi.org/10.1007/s007030050011, 2000.

Buzzi, A., D'Isidoro, M., and Davolio, S.: A case study of an orographic cyclone formation south of the Alps during the MAPSOP, Q. J. Roy. Meteor. Soc., 129, 1795-1818, 2003.

Buzzi, A., Davolio, S., Malguzzi, P., Drofa, O., and Mastrangelo, D.: Heavy rainfall episodes over Liguria in autumn 2011: numerical forecasting experiments, Nat. Hazards Earth Syst. Sci., 14, 1325-1340, https://doi.org/10.5194/nhess-14-1325-2014, 2014.

Buzzi, A., Davolio, S., and Fantini, M.: Cyclogenesis in the lee of the Alps: a review of theories, Bull. of Atmos. Sci. and Technol. 1, 433-457, https://doi.org/10.1007/s42865-020-00021-6, 2020a.

Buzzi, A., Di Muzio, E., and Malguzzi, P.: Barrier winds in the Italian region and effects of moist processes, Bull. of Atmos. Sci. and Technol., 1, 59-90, https://doi.org/10.1007/s42865-02000005-6, 2020b.

Caldas-Alvarez, A. and Khodayar, S.: Assessing atmospheric moisture effects on heavy precipitation during HyMeX IOP16 using GPS nudging and dynamical downscaling, Nat. Hazards Earth Syst. Sci., 20, 2753-2776, https://doi.org/10.5194/nhess20-2753-2020, 2020.

Cassola, F., Ferrari, F., Mazzino, A., and Miglietta M. M.: The role of the sea on the flash floods events over Liguria (Italy), Geophys. Res. Lett., 43, 3534-3542, https://doi.org/10.1002/2016GL068265, 2016.

Caccamo, M. T., Castorina, G., Colombo, F., Insinga, V., Maiorana, E., and Magazù, S.: Weather forecast performances for complex orographic areas: Impact of different grid resolutions and of geographic data on heavy rainfall event simulations in Sicily, Atmos. Res., 198, 22-33, 2017.

Cavaleri, L., Bajo, M., Barbariol, F., Bastianin, M., Benetazzo, A., Bertotti, L., Chiggiato, J., Davolio, S., Ferrarin, C., Magnusson, L., Papa, A., Pezzutto, P., Pomaro, A., and Umgeisser, G.: The October 29, 2018 storm in Northern Italy - An exceptional event and its modeling, Prog. Oceanogr., 178, 102178, https://doi.org/10.1016/j.pocean.2019.102178, 2019.

Chazette, P., Flamant, C., Shang, X., Totems, J., Raut, J.-C., Doerenbecher, A., Ducrocq, V., Fourrié, N., Bock, O., and Cloché, S.: A multi-instrument and multi-model assessment of atmospheric moisture variability over the western Mediter- ranean during HyMeX, Q. J. Roy. Meteor. Soc., 142, 7-22, https://doi.org/10.1002/qj.2671, 2016.

Chen, S. H. and Lin, Y. L.: Effects of moist Froude number and CAPE on a conditionally unstable flow over meso-scale mountain ridge, J. Atmos. Sci., 62, 331-350, 2005.

Crespi, A., Brunetti, M., Lentini, G., and Maugeri, M.: 1961-1990 high-resolution monthly precipitation climatologies for Italy, Int. J. Climate, 38, 878-895, 2018.

Davolio, S., Buzzi, A., and Malguzzi, P.: Orographic influence on deep convection: case study and sensitivity experiments, Meteorol. Z., 15, 215-223, 2006.

Davolio, S., Buzzi, A., and Malguzzi, P.: Orographic triggering of long-lived convection in three dimensions, Meteorol. Atmos. Phys., 103, 35-44, 2009.

Davolio, S., Ferretti, R., Baldini, L., Casaioli, M., Cimini, D., Ferrario, M. E., Gentile, S., Loglisci, N., Maiello, I., Manzato, A., Mariani, S., Marsigli, C., Marzano, F. S., Miglietta, M. M., Montani, A., Panegrossi, G., Pasi, F., Pichelli, E., Pucillo, A., and Zinzi, A.: The role of the Italian scientific community in the first HyMeX SOP: an outstanding multidisciplinary experience, Meteorol. Z., 24, 261-267, https://doi.org/10.1127/metz/2014/0624, 2015a.

Davolio, S., Silvestro, F., and Malguzzi, P.: Effects of Increasing Horizontal Resolution in a Convection Permitting Model on Flood Forecasting: The 2011 Dramatic Events in Liguria (Italy), J. Hydrometeorol., 16, 1843-1856, https://doi.org/10.1175/JHMD-14-0094.1, 2015b

Davolio, S., Volontè, A., Manzato, A., Pucillo, A., Cicogna, A., and Ferrario, M. E.: Mechanisms producing different precipitation patterns over North-Eastern Italy: insights from HyMeXSOP1 and previous events, Q. J. Roy. Meteor. Soc., 142, 188205, https://doi.org/10.1002/qj.2731, 2016.

Davolio, S., Henin, R., Stocchi, P., and Buzzi, A.: Bora wind and heavy persistent precipitation: Atmospheric water balance and role of air-sea fluxes over the Adriatic Sea, Q. J. Roy. Meteor. Soc., 143, 1165-1177, https://doi.org/10.1002/qj.3002, 2017.

Davolio, S., Della Fera, S., Laviola, S., Miglietta, M. M., and Levizzani, V.: An atmospheric river in the Mediterranean basin: the 29 October 2018 "Vaia" storm over Italy, Mon. Weather Rev., 148, 3571-3588, https://doi.org/10.1175/MWRD-20-0021.1, 2020.

Drobinski, P., Ducrocq, V., Alpert, P., Anagnostou, E., Beìranger, K., Borga, M., Braud, I., Chanzy, A., Davolio, S., Delrieu, G., Estournel, C., Filali Boubrahmi, N., Font, J., Grubisic, V., Gualdi, S., Homar, V., Ivancan-Picek, B., Kottmeier, C., Kotroni, V., Lagouvardos, K., Lionello, P., Llasat, M. C., Ludwig, W., Lutoff, C., Mariotti, A., Richard, E., Romero, R., Rotunno, R., Roussot, O., Ruin, I., Somot, S., Taupier-Letage, I., Tintore, J., Uijlenhoet, R., and Wernli, H.: HyMeX, a 10-year multidisciplinary program on the Mediterranean water cycle, B. Am. Meteorol. Soc., 95, 1063-1082, https://doi.org/10.1175/BAMS-D12-00242.1, 2014.

Ducrocq, V., Nuissier, O., Ricard, D., Lebeaupin, C., and Thouvenin, T.: A numerical study of three catastrophic precipitating events over southern France. Part II: Mesoscale triggering and stationarity factors, Q. J. Roy. Meteor. Soc., 134, 131-145, 2008.

Ducrocq, V., Braud, I., Davolio, S., Ferretti, R., Flamant, C., Jansa, A., Kalthoff, N., Richard, E., Taupier-Letage, I., Ayral, P.-A., Belamari, S., Berne, A., Borga, M., Boudevillain, B., Bock, O., 
Boichard, J.-L., Bouin, M.-N., Bousquet, O., Bouvier, C., Chiggiato, J., Cimini, D., Corsmeier, U., Coppola, L., Cocquerez, P., Defer, E., Drobinski, P., Dufournet, Y., Fourrié, N., Gourley, J. J., Labatut, L., Lambert, D., Le Coz, J., Marzano, F. S., Molinié, G., Montani, A., Nord, G., Nuret, M., Ramage, K., Rison, B., Roussot, O., Said, F., Schwarzenboeck, A., Testor, P., Van Baelen, J., Vincendon, B., Aran, M., and Tamayo, J.: HyMeX SOP1, the field campaign dedicated to heavy precipitation and flash flooding in the northwestern Mediterranean, B. Am. Meteorol. Soc., 95, 1083-1100, https://doi.org/10.1175/BAMS-D-1200244.1, 2014.

Ducrocq, V., Davolio, S., Ferretti, R., Flamant, C., Homar Santaner, V., Kalthoff, N., Richard, E., and Wernli, H.: Introduction to the HyMeX Special Issue on "Advances in understanding and forecasting of heavy precipitation in the Mediterranean through the HyMeX SOP1 field campaign", Q. J. Roy. Meteor. Soc., 142, 16, https://doi.org/10.1002/qj.2856, 2016.

Duffourg, F. and Ducrocq, V.: Origin of the moisture feeding the Heavy Precipitating Systems over Southeastern France, Nat. Hazards Earth Syst. Sci., 11, 1163-1178, https://doi.org/10.5194/nhess-11-1163-2011, 2011.

Duffourg, F. and Ducrocq, V.: Assessment of the water supply to Mediterranean heavy precipitation: a method based on finely designed water budgets, Atmos. Sci. Lett., 14, 133-138, https://doi.org/10.1002/asl2.429, 2013.

Duffourg, F., Nuissier, O., Ducrocq, V., Flamant, C., Chazette, P., Delanoë, J., Doerenbecher, A., Fourrié, N., Di Girolamo, P., Lac, C., Legain, D., Martinet, M., Said, F., and Bock, O.: Offshore deep convection initiation and maintenance during the HyMeX IOP 16a heavy precipitation event, Q. J. Roy. Meteor. Soc., 142, 259-274, https://doi.org/10.1002/qj.2725, 2016.

Duffourg, F., Lee, K. O., Ducrocq, V., Flamant, C., Chazette, P., and Di Girolamo, P.: Role of moisture patterns in the backbuilding formation of HyMeX IOP13 Heavy Precipitating Systems, Q. J. Roy. Meteor. Soc., 144, 291-303, https://doi.org/10.1002/qj.3201, 2018.

Federico, S., Avolio, E., Petracca, M., Panegrossi, G., Sanò, P., Casella, D., and Dietrich, S.: Simulating lightning into the RAMS model: implementation and preliminary results, Nat. Hazards Earth Syst. Sci., 14, 2933-2950, https://doi.org/10.5194/nhess-14-2933-2014, 2014.

Ferretti, R., Panegrossi, G., Rotunno, R., Pichelli, E., Marzano, F. S., Dietrich, S., Picciotti, E., and Vulpiani, G.: An analysis of three disastrous rain events occurred in Italy: Rome, Cinque Terre and Genoa, Proc. of the 14th EGU Plinius Conf. on Mediterranean Storms and MEDEX Final Conf., Palma de Mallorca, Spain, 13-15 November, https://meetingorganizer. copernicus.org/Plinius14/Plinius14-30.pdf (last access: 4 February 2022), 2012.

Ferretti, R., Pichelli, E., Gentile, S., Maiello, I., Cimini, D., Davolio, S., Miglietta, M. M., Panegrossi, G., Baldini, L., Pasi, F., Marzano, F. S., Zinzi, A., Mariani, S., Casaioli, M., Bartolini, G., Loglisci, N., Montani, A., Marsigli, C., Manzato, A., Pucillo, A., Ferrario, M. E., Colaiuda, V., and Rotunno, R.: Overview of the first HyMeX Special Observation Period over Italy: observations and model results, Hydrol. Earth Syst. Sci., 18, 1953-1977, https://doi.org/10.5194/hess-18-1953-2014, 2014.

Feudale, L. and Manzato, A.: Cloud-to-ground lightning distribution and its relationship with orography and anthropogenic emis- sions in the Po Valley, J. Appl. Meteorol. Clim., 53, 2651-2670, 2014.

Flaounas, E., Fita, L., Lagouvardos, K., and Kotroni, V.: Heavy rainfall in Mediterranean cyclones, Part II: Water budget, precipitation efficiency and remote water sources, Clim. Dynam., 53, 2539-2555, https://doi.org/10.1007/s00382-019-04639-x, 2019.

Fiori, E., Comellas, A., Molini, L., Rebora, N., Siccardi, F., Gochis, D., Tanelli, S., and Parodi, A.: Analysis and hindcast simulations of an extreme rainfall event in the Mediterranean area: The Genoa 2011 case, Atmos. Res., 138, 13-29, 2014.

Fiori, E., Ferraris, L., Molini, L., Siccardi, F., Kranzlmueller, D., and Parodi, A.: Triggering and evolution of a deep convective system in the Mediterranean Sea: modelling and observations at a very fine scale, Q. J. Roy. Meteor. Soc., 143, 927-941, https://doi.org/10.1002/qj.2977, 2017.

Fujita, T. T.: Manual of downburst identification for project Nimrod, Satellite and Mesometeorology Research Paper 156, Dept. of Geophysical Sciences, University of Chicago, 104 pp., [NTIS PB-286048], http://hdl.handle.net/10605/261961 (last access: 4 February 2022), 1978.

Funatsu, B., Claud, M. C., and Chaboureau, J. P.: Comparison between the large scale environments of moderate and intense precipitating systems in the Mediterranean region, Mon. Weather Rev., 137, 3933-3959, 2009.

Gascon, E., Laviola, S., Merino, A., and Miglietta, M. M.: Analysis of a localized flash-flood event over the central Mediterranean, Atmos. Res., 182, 256-268, https://doi.org/10.1016/j.atmosres.2016.08.007, 2016.

Giaiotti, D. B., Giovannoni, M., Pucillo, A., and Stel, F.: The climatology of tornadoes and waterspouts in Italy, Atmos. Res., 83, 534-541, 2007.

Giovannini, L., Davolio, S., Zaramella, M., Zardi, D., and Borga, M.: Multi-model convection-resolving simulations of the October 2018 Vaia storm over Northeastern Italy, Atmos. Res., 253, 1-20, https://doi.org/10.1016/j.atmosres.2021.105455, 2021.

Grazzini, F.: Predictability of a large-scale flow conducive to extreme precipitation over the western Alps, Meteorol. Atmos. Phys., 95, 123-138, https://doi.org/10.1007/s00703-006-0205-8, 2007.

Grazzini, F., Craig, G. C., Keil, C., Antolini, G., and Pavan, V.: Extreme precipitation events over northern Italy. Part I: A systematic classification with machine-learning techniques, Q. J. Roy. Meteor. Soc., 146, 69-85, https://doi.org/10.1002/qj.3635, 2019.

Guzzetti, F., Stark, C. P., and Salvati, P.: Evaluation of flood and landslide risk to the population of Italy, Environ. Manage., 36, 15-36, 2005.

Homar, V., Romero, R., Stensrud, D. J., Ramis, C., and Alonso, S.: Numerical diagnosis of a small, quasi-tropical cyclone over the westernMediterranean: Dynamical versus boundary factors, Q. J. Roy. Meteor. Soc., 129, 1469-1490, 2003.

Horvath, K., Ivatek-Sahdan, S., Ivančan-Picek, B., and Grubišić, V.: Evolution and structure of two severe cyclonic Bora events: contrast between the northern and southern Adriatic, Weather Forecast., 24, 946-964, 2009.

Isotta, F. A., Frei, C., Weilguni, V., Perčec Tadić, M., Lassègues, P., Rudolf, B., Pavan, V., Cacciamani, C., Antolini, G., Ratto, S. M., Munari, M., Micheletti, S., Bonati, V., Lussana, C., Ronchi, C., Panettieri, E., Marigo, G., and Vertačnik, G.: The climate of daily precipitation in the Alps: development and analysis of a high- 
resolution grid dataset from pan-Alpine rain-gauge data, Int. J. Climatol., 34, 1657-1675, https://doi.org/10.1002/joc.3794, 2014.

Jansa, A., Genoves, A., Picornell, M. A., Campins, J., Riosalido, R., and Carretero, O.: Western Mediterranean cyclones and heavy rain, Part 2: Statistical approach, Meteorol. Appl., 8, 43-56, 2001.

Jansa, A., Alpert, P., Arbogast, P., Buzzi, A., Ivancan-Picek, B., Kotroni, V., Llasat, M. C., Ramis, C., Richard, E., Romero, R., and Speranza, A.: MEDEX: a general overview, Nat. Hazards Earth Syst. Sci., 14, 1965-1984, https://doi.org/10.5194/nhess14-1965-2014, 2014.

Khodayar, S., Fosser, G., Berthou, S., Davolio, S., Drobinski, P., Ducrocq, V., Ferretti,R., Nuret, M., Pichelli, E., Richard, E., and Bock, O.: A seamless weather-climate multi-model intercomparison on the representation of a high impact weather event in the western Mediterranean: HyMeX IOP12, Q. J. Roy. Meteor. Soc., 142, 433-452, https://doi.org/10.1002/qj.2700, 2016.

Khodayar, S., Czajka, B., Caldas-Alvarez, A., Helgert, S., Flamant, C., Di Girolamo, P., Bock, O., and Chazette, P.: Multi-scale Observations of Moisture Feeding Heavy Precipitating Systems in the North-western Mediterranean during HyMeX IOP12, Q. J. Roy. Meteor. Soc., 144, 2761-2780, https://doi.org/10.1002/qj.3402, 2018.

Kirshbaum, D. J. and Straub, D. N.: Linear theory of shallow convection in deep, vertically sheared atmospheres, Q. J. Roy. Meteor. Soc., 145, 3129-3147, 2019.

Krichak, S. O., Barkan, J., Breitgand, J. S., Gualdi, S., and Feldstein, S. B.: The role of the export of tropical moisture into midlatitudes for extreme precipitation events in the Mediterranean region, Theor. Appl. Climatol., 121, 499-515, https://doi.org/10.1007/s00704-014-1244-6, 2015.

Lebeaupin Brossier, C., Ducrocq, V., and Giordani, H.: Sensitivity of three Mediterranean heavy rain events to two different sea surface fluxes parameterizations in highresolution numerical modeling, J. Geophys. Res., 113, D21109, https://doi.org/10.1029/2007JD009613, 2008.

Lee, K.-O., Flamant, C., Ducrocq, V., Duffourg, F., Fourrié, N., and Davolio, S.: Convective initiation and maintenance processes of two back-building mesoscale convective systems leading to heavy precipitation events in Southern Italy during HyMeX IOP 13, Q. J. Roy. Meteor. Soc., 142, 2623-2635, https://doi.org/10.1002/qj.2978, 2016.

Lee, K.-O., Flamant, C., Ducrocq, V., Duffourg, F., Fourrié, N., Delanoë, J., and Bech, J.: Initiation and development of a mesoscale convective system in the Ebro River Valley and related heavy precipitation over north-eastern Spain during HyMeX IOP 15a, Q. J. Roy. Meteor. Soc., 143, 942-956, https://doi.org/10.1002/qj.2978, 2017.

Lee, K.-O., Flamant, C., Duffourg, F., Ducrocq, V., and Chaboureau, J.-P.: Impact of upstream moisture structure on a back-building convective precipitation system in south-eastern France during HyMeX IOP13, Atmos. Chem. Phys., 18, 1684516862, https://doi.org/10.5194/acp-18-16845-2018, 2018.

Lee, K.-O., Aemisegger, F., Pfahl, S., Flamant, C., Lacour, J.-L., and Chaboureau, J.-P.: Contrasting stable water isotope signals from convective and large-scale precipitation phases of a heavy precipitation event in southern Italy during HyMeX IOP 13: a modelling perspective, Atmos. Chem. Phys., 19, 7487-7506, https://doi.org/10.5194/acp-19-7487-2019, 2019.

Ličer, M., Smerkol, P., Fettich, A., Ravdas, M., Papapostolou, A., Mantziafou, A., Strajnar, B., Cedilnik, J., Jeromel, M., Jerman, J., Petan, S., Malačič, V., and Sofianos, S.: Modeling the ocean and atmosphere during an extreme bora event in northern Adriatic using one-way and two-way atmosphere-ocean coupling, Ocean Sci., 12, 71-86, https://doi.org/10.5194/os-12-71-2016, 2016.

Lin, Y-L., Chiao, S., Wang, T.-A., Kaplan, M. L., and Weglarz, R. P.: Some common ingredients for heavy orographic rainfall, Weather Forecast., 16, 633-660, 2001.

Llasat, M. C., Llasat-Botija, M., Petrucci, O., Pasqua, A. A., Rosselló, J., Vinet, F., and Boissier, L.: Towards a database on societal impact of Mediterranean floods within the framework of the HYMEX project, Nat. Hazards Earth Syst. Sci., 13, 13371350, https://doi.org/10.5194/nhess-13-1337-2013, 2013.

Lombardi, A., Colaiuda, V., Verdecchia, M., and Tomassetti, B.: User-oriented hydrological indices for early warning systems with validation using post-event surveys: flood case studies in the Central Apennine District, Hydrol. Earth Syst. Sci., 25, 19691992, https://doi.org/10.5194/hess-25-1969-2021, 2021.

Maiello, I., Gentile, S., Ferretti, R., Baldini, L., Roberto, N., Picciotti, E., Alberoni, P. P., and Marzano, F. S.: Impact of multiple radar reflectivity data assimilation on the numerical simulation of a flash flood event during the HyMeX campaign, Hydrol. Earth Syst. Sci., 21, 5459-5476, https://doi.org/10.5194/hess-21-54592017, 2017.

Manzato, A.: Hail in NE Italy: Climatology and bivariate analysis with the sounding-derived indices, J. Appl. Meteorol. Clim., 51, 449-467, 2012.

Manzato, A., Davolio, S., Miglietta, M. M., Pucillo, A., and Setvak, M.: 12 September 2012: A supercell outbreak in NE Italy?, Atmos. Res., 153, 98-118, 2015.

Manzato, A., Cicogna, A., and Pucillo, A.: 6-hour maximum rain in Friuli Venezia Giulia: Climatology and ECMWF-based forecasts, Atmos. Res., 169, 465-484, https://doi.org/10.1016/j.atmosres.2015.07.013, 2016.

Manzato, A., Riva, V., Tiesi, A., and Miglietta, M.M.: Analysis of the 4 July 2007 hailstorm in NE Italy, Q. J. Roy. Meteor. Soc., 146, 3587-3611, https://doi.org/10.1002/qj.3886, 2020.

Marra, A. C., Federico, S., Montopoli, M., Avolio, E., Baldini, L., Casella, D., D’Adderio, L. P., Dietrich, S., Sanò, P., Torcasio, R. C., and Panegrossi, G.: The precipitation structure of the Mediterranean tropical-like cyclone Numa: analysis of GPM observations and numerical weather prediction model simulations, Remote Sens., 11, 1690, https://doi.org/10.3390/rs11141690, 2019.

Martinotti, M. E., Pisano, L., Marchesini, I., Rossi, M., Peruccacci, S., Brunetti, M. T., Melillo, M., Amoruso, G., Loiacono, P., Vennari, C., Vessia, G., Trabace, M., Parise, M., and Guzzetti, F.: Landslides, floods and sinkholes in a karst environment: the 16 September 2014 Gargano event, southern Italy, Nat. Hazards Earth Syst. Sci., 17, 467-480, https://doi.org/10.5194/nhess-17467-2017, 2017.

Mastrangelo, D., Horvath, K., Riccio, A., and Miglietta, M. M.: Mechanisms for convection development in a long-lasting heavy precipitation event over southeastern Italy, Atmos. Res, 100, 586-602, https://doi.org/10.1016/j.atmosres.2010.10.010, 2011. 
Mazzarella, V., Maiello, I., Capozzi, V., Budillon, G., and Ferretti, R.: Comparison between 3D-Var and 4D-Var data assimilation methods for the simulation of a heavy rainfall case in central Italy, Adv. Sci. Res., 14, 271-278, https://doi.org/10.5194/asr14-271-2017, 2017.

Miglietta, M. M. and Buzzi, A.: A numerical study of moist stratified flows over isolated topography, Tellus, 53A, 481-499, 2001.

Miglietta, M. M. and Buzzi, A.: A numerical study of moist stratified flow regimes over isolated topography, Q. J. Roy. Meteor. Soc., 130, 1749-1770. https://doi.org/10.1256/qj.02.225, 2004.

Miglietta, M. M. and Rotunno, R.: Simulations of moist nearly neutral flow over a ridge, J. Atmos. Sci, 62, 1410-1427, 2005.

Miglietta, M. M. and Rotunno, R.: Further results on moist nearly neutral flow over a ridge, J. Atmos. Sci., 63, 2881-2897, https://doi.org/10.1175/JAS3793.1, 2006.

Miglietta, M. M. and Regano, A.: An observational and numerical study of a flash-flood event over south-eastern Italy, Nat. Hazards Earth Syst. Sci., 8, 1417-1430, https://doi.org/10.5194/nhess-81417-2008, 2008.

Miglietta, M. M. and Rotunno, R.: Numerical simulations of conditionally unstable flows over a ridge, J. Atmos. Sci., 66, 1865$1885,2009$.

Miglietta, M. M. and Rotunno, R.: Numerical simulations of lowCAPE flows over a mountain ridge, J. Atmos. Sci., 67, 23912401, 2010

Miglietta, M. M. and Rotunno, R.: Application of theory to observed cases of orographically forced convective rainfall, Mon. Weather Rev., 140, 3039-3053, 2012.

Miglietta, M. M. and Rotunno, R.: Numerical simulations of sheared conditionally unstable flows over a mountain ridge, J. Atmos. Sci., 71, 1747-1762, 2014.

Miglietta, M. M., Manzato, A., and Rotunno, R.: Characteristics and predictability of a supercell during HyMeX SOP1, Q. J. Roy. Meteor. Soc., 142, 2839-2853, 2016.

Monai, M., Rossa, A. M., and Bonan, A. C.: Partitioning of snowy and rainy precipitation in a case of a north Adriatic frontal passage, Adv. Geosci., 7, 279-284, https://doi.org/10.5194/adgeo-7279-2006, 2006.

Moscatello, A., Miglietta, M. M., and Rotunno, R.: Numerical analysis of a Mediterranean "hurricane" over south-eastern Italy, Mon. Weather Rev., 136, 4373-4397, https://doi.org/10.1175/2008MWR2512.1, 2008.

Nuissier, O., Ducrocq, V., Ricard, D., Lebeaupin, C., and Anquetin, S.: A numerical study of three catastrophic precipitating events over southern France. I: Numerical framework and synoptic ingredients, Q. J. Roy. Meteor. Soc., 134, 111-130, https://doi.org/10.1002/qj.200, 2008.

Nuissier, O., Joly, B., Joly, A., Ducrocq, V., and Arbogast, P.: A statistical downscaling to identify the large-scale circulation patterns associated with heavy precipitation events over southern France, Q. J. Roy. Meteor. Soc., 137, 1812-1827, https://doi.org/10.1002/qj.866, 2011.

Nuissier, O., Marsigli, C., Vincendon, B., Hally, A., Bouttier, F., Montani, A., and Paccagnella, T.: Evaluation of two convectionpermitting ensemble systems in the HyMeX Special Observation Period (SOP1) framework, Q. J. Roy. Meteor. Soc., 142, 404 418, https://doi.org/10.1002/qj.2859, 2016.

Pichelli, E., Rotunno, R., and Ferretti, R.: Effects of the Alps and Apennines on forecasts for Po Valley convection in two
HyMeX cases, Q. J. Roy. Meteor. Soc., 143, 2420-2435, https://doi.org/10.1002/qj.3096, 2017.

Pinto, J. G., Ulbrich, S., Parodi, A., Rudari, R., Boni, G., and Ulbrich, U.: Identification and ranking of extraordinary rainfall events over Northwest Italy: The role of Atlantic moisture, J. Geophys. Res., 118, 2085-2097, https://doi.org/10.1002/JGRD.50179, 2013.

Pontrelli, M. D., Bryan, G. H., and Fritsch, J. M.: The Madison County, Virginia, flash flood of 27 June 1995, Weather Forecast., 14, 384-404, 1999.

Pucillo, A. and Manzato, A.: 08/08/08: The "Olympic storm" event and its implication about severe weather, in: IV HyMeX Workshop, Bologna, Italy, 8-10 June, https://www.hymex.org/public/ workshops/4/BOOK_OF_ABSTRACT_HYMEX_2010.pdf (last access: 4 February 2022), 2010.

Pucillo, A., Miglietta, M. M., Lombardo, K., and Manzato, A.: Application of a simple analytical model to the study of a bow echo-like storm in Northeastern Italy, Met. Appl., 27, e1868, https://doi.org/10.1002/met.1868, 2020.

Punge, H. J., Bedka, K., Kunz, M., and Werner, A.: A new physically based stochastic event catalog for hail in Europe, Nat. Hazards, 73, 1625-1645, 2014.

Rainaud, R., Lebeaupin Brossier, C., Ducrocq, V., Giordani, H., Nuret, M., Fourriè, N., Bouin, M.-N., Taupier-Letage, I., and Legain, D.: Characterisation of air-sea exchanges over the Western Mediterranean Sea during the HyMeX SOP1 using the AROME-WMED model, Q. J. Roy. Meteor. Soc., 142, 173-187, https://doi.org/10.1002/qj.2480, 2016.

Rainaud, R., Lebeaupin Brossier, C., Ducrocq, V., and Giordani, H.: High-resolution air-sea coupling impact on two heavy precipitation events in the Western Mediterranean, Q. J. Roy. Meteor. Soc., 143, 2448-2462, 2017.

Rebora, N., Molini, L., Casella, E., Comellas, A., Fiori, E., Pignone, F., Siccardi, F., Silvestro, F., Tanelli, S., and Parodi, A.: Extreme rainfall in the Mediterranean: What can we learn from observations?, J. Hydrometeor., 14, 906-922, 2013.

Ricard, D., Ducrocq, V., and Auger, L.: A climatology of the mesoscale environment associated with heavily precipitating avents over the Northwestern Mediterranean area, J. Appl. Meteor. Clim., 51, 468-488, 2012.

Ricchi, A., Miglietta, M. M., Falco, P. P., Benetazzo, A., Bonaldo, D., Bergamasco, A., Sclavo, M., and Carniel, S.: On the use of a coupled ocean-atmosphere-wave model during an extreme cold air outbreak over the Adriatic Sea, Atmos. Res., 172, 48-65, 2016.

Ricchi, A., Bonaldo, D., Cioni, G., Carniel, S., and Miglietta, M. M.: Simulation of a flash-flood event over the Adriatic Sea with a high-resolution atmosphere-ocean-wave coupled system, Sci. Rep., 11, 9388, https://doi.org/10.1038/s41598-021-88476$1,2021$.

Roberto, N., Adirosi, E., Baldini, L., Casella, D., Dietrich, S., Gatlin, P., Panegrossi, G., Petracca, M., Sanò, P., and Tokay, A.: Multi-sensor analysis of convective activity in central Italy during the HyMeX SOP 1.1, Atmos. Meas. Tech., 9, 535-552, https://doi.org/10.5194/amt-9-535-2016, 2016.

Rotunno, R. and Ferretti, R.: Mechanisms of intense Alpine rainfall, J. Atmos. Sci., 58, 1732-1749, 2001. 
Rotunno, R. and Houze, R. A.: Lessons on orographic precipitation from the Mesoscale Alpine Programme, Q. J. Roy. Meteor. Soc., 133, 811-830, https://doi.org/10.1002/qj.67, 2007.

Rotunno, R. and Klemp, J. B.: On the rotation and propagation of simulated supercell thunderstorms, J. Atmos. Sci., 42, 271-292, 1985.

Salvati, P., Bianchi, C., Rossi, M., and Guzzetti, F.: Societal landslide and flood risk in Italy, Nat. Hazards Earth Syst. Sci., 10, 465-483, https://doi.org/10.5194/nhess-10-465-2010, 2010.

Scheffknecht, P., Richard, E., and Lambert, D.: A highly localized high-precipitation event over Corsica, Q. J. Roy. Meteor. Soc., 142, 206-221, https://doi.org/10.1002/qj.2795, 2016.

Schumacher, R. S. and Johnson, R. H.: Organization and environmental properties of extreme-rain-producing mesoscale convective systems, Mon. Weather Rev., 133, 961-976, 2005.

Senatore, A., Davolio, S., Furnari, L., and Mendicino, G.: Reconstructing flood events in Mediterranean coastal areas using different reanalyses and high-resolution meteorological models, J. Hydrometeor., 21, 1865-1887, 2020.

Serafin, S., Adler, B., Cuxart, J., De Wekker, S. F. J., Gohm, A., Grisogono, B., Kalthoff, N., Kirshbaum, D. J., Rotach, M. W., Schmidli, J., Stiperski, I., Večenaj, Ž., and Zardi, D.: Exchange Processes in the Atmospheric Boundary Layer Over Mountainous Terrain, Atmosphere, 9, 102, https://doi.org/10.3390/atmos9030102, 2018.

Silvestro, F., Gabellani, S., Giannoni, F., Parodi, A., Rebora, N., Rudari, R., and Siccardi, F.: A hydrological analysis of the 4 November 2011 event in Genoa, Nat. Hazards Earth Syst. Sci., 12, 2743-2752, https://doi.org/10.5194/nhess-122743-2012, 2012.

Silvestro, F., Rebora, N., Rossi, L., Dolia, D., Gabellani, S., Pignone, F., Trasforini, E., Rudari, R., De Angeli, S., and Masciulli, C.: What if the 25 October 2011 event that struck Cinque Terre (Liguria) had happened in Genoa, Italy? Flooding scenarios, hazard mapping and damage estimation, Nat. Hazards Earth Syst. Sci., 16, 1737-1753, https://doi.org/10.5194/nhess16-1737-2016, 2016.
Stensrud, D. J.: Importance of low-level jets to climate: A review, J. Climate, 9, 1698-1711, 1996.

Stocchi, P. and Davolio, S.: Intense air-sea exchanges and heavy orographic precipitation over Italy: The role of the Adriatic Sea surface temperature uncertainty, Atmos. Res., 196, 62-82, https://doi.org/10.1016/j.atmosres.2017.06.004, 2017.

Thévenot, O., Bouin, M.-N., Ducrocq, V., Lebeaupin Brossier, C., Nuissier, O., Pianezze, J., and Duffourg, F.: Influence of the sea state on Mediterranean heavy precipitation: A case study from HyMeX SOP1, Q. J. Roy. Meteor. Soc., 142, 377-389, https://doi.org/10.1002/qj.2660, 2016.

Torcasio, R. C., Federico, S., Comellas Prat, A., Panegrossi, G., D'Adderio, L. P., and Dietrich, S.: Impact of Lightning Data Assimilation on the Short-Term Precipitation Forecast over the Central Mediterranean Sea, Remote Sens., 13, 682, https://doi.org/10.3390/rs13040682, 2021.

Turato, B., Reale, O., and Siccardi, F.: Water vapor sources of the October 2000 Piedmont flood, J. Hydrometeor., 5, 693-712, https://doi.org/10.1175/15257541(2004)005<0693:WVSOTO>2.0.CO;2, 2004.

Vulpiani, G., Montopoli, M., Delli Passeri, L., Gioia, A., Giordano, P., and Marzano, F. S.: On the use of dual-polarized C-band radar for operational rainfall retrieval in mountainous areas, J. Appl. Meteor. Clim., 51, 405-425, 2012.

Xie, S. P., Xu, H. M., Kessler, W. S., and Nonaka, M.: Air-sea interaction over the eastern Pacific warm pool: Gap winds, thermocline dome, and atmospheric convection, J. Climate, 18, 5-20, 2005.

Winschall, A., Pfahl, S., Sodemann, H., and Wernli, H.: Impact of North Atlantic evaporation hot spots on southern Alpine heavy precipitation events, Q. J. Roy. Meteor. Soc., 138, 1245-1258, 2012. 